\title{
Variations in the chemical composition of the submicron aerosol and in the sources of the organic fraction at a regional background site of the Po Valley (Italy)
}

\author{
Michael Bressi ${ }^{1}$, Fabrizia Cavalli ${ }^{1}$, Claudio A. Belis ${ }^{1}$, Jean-Philippe Putaud ${ }^{1}$, Roman Fröhlich ${ }^{2}$, \\ Sebastiao Martins dos Santos ${ }^{1}$, Ettore Petralia ${ }^{3}$, André S. H. Prévôt ${ }^{2}$, Massimo Berico ${ }^{3}$, Antonella Malaguti ${ }^{3}$, and \\ Francesco Canonaco $^{2}$ \\ ${ }^{1}$ European Commission, Joint Research Centre, Institute for Environment and Sustainability, Air and Climate Unit, \\ Via Enrico Fermi 2749, Ispra (VA) 21027, Italy \\ ${ }^{2}$ Paul Scherrer Institute, Laboratory of Atmospheric Chemistry, Villigen 5232, Switzerland \\ ${ }^{3}$ Italian National Agency for New Technologies, Energy and Sustainable Economic Development (ENEA), \\ Via Martiri di Monte Sole 4, Bologna 40129, Italy
}

Correspondence to: Michael Bressi (michael.s.bressi@gmail.com), Claudio A. Belis (claudio.belis@jrc.ec.europa.eu), and Fabrizia Cavalli (fabrizia.cavalli@jrc.ec.europa.eu)

Received: 1 February 2016 - Published in Atmos. Chem. Phys. Discuss.: 22 February 2016

Revised: 2 August 2016 - Accepted: 16 August 2016 - Published: 18 October 2016

\begin{abstract}
Fine particulate matter (PM) levels and resulting impacts on human health are in the Po Valley (Italy) among the highest in Europe. To build effective PM abatement strategies, it is necessary to characterize fine PM chemical composition, sources and atmospheric processes on long timescales ( $>$ months), with short time resolution (< day), and with particular emphasis on the predominant organic fraction. Although previous studies have been conducted in this region, none of them addressed all these aspects together. For the first time in the Po Valley, we investigate the chemical composition of nonrefractory submicron PM (NR-PM $\left.{ }_{1}\right)$ with a time resolution of $30 \mathrm{~min}$ at the regional background site of Ispra during 1 full year, using the Aerodyne Aerosol Chemical Speciation Monitor (ACSM) under the most upto-date and stringent quality assurance protocol. The identification of the main components of the organic fraction is made using the Multilinear-Engine 2 algorithm implemented within the latest version of the SoFi toolkit. In addition, with the aim of a potential implementation of ACSM measurements in European air quality networks as a replacement of traditional filter-based techniques, parallel multiple offline analyses were carried out to assess the performance of the ACSM in the determination of PM chemical species regulated by air quality directives. The annual NR-PM 1 level
\end{abstract}

monitored at the study site $\left(14.2 \mu \mathrm{g} \mathrm{m}^{-3}\right)$ is among the highest in Europe and is even comparable to levels reported in urban areas like New York City and Tokyo. On the annual basis, submicron particles are primarily composed of organic aerosol (OA, $58 \%$ of NR-PM $)_{1}$. This fraction was apportioned into oxygenated OA (OOA, $66 \%$ ), hydrocarbon-like OA (HOA, $11 \%$ of OA) and biomass burning OA (BBOA, $23 \%)$. Among the primary sources of OA, biomass burning $(23 \%)$ is thus bigger than fossil fuel combustion (11\%). Significant contributions of aged secondary organic aerosol (OOA) are observed throughout the year. The unexpectedly high degree of oxygenation estimated during wintertime is probably due to the contribution of secondary BBOA and the enhancement of aqueous-phase production of OOA during cold months. BBOA and nitrate are the only components of which contributions increase with the NR-PM ${ }_{1}$ levels. Therefore, biomass burning and $\mathrm{NO}_{x}$ emission reductions would be particularly efficient in limiting submicron aerosol pollution events. Abatement strategies conducted during cold seasons appear to be more efficient than annual-based policies. In a broader context, further studies using high-timeresolution analytical techniques on a long-term basis for the characterization of fine aerosol should help better shape our future air quality policies, which constantly need refinement. 


\section{Introduction}

The Po Valley region - located in northern Italy - is amongst the most polluted areas in Europe (van Donkelaar et al., 2010; EEA, 2013). Annual $\mathrm{PM}_{2.5}$ (particulate matter with an aerodynamic diameter below $2.5 \mu \mathrm{m}$ ) mean concentrations can significantly exceed the European $\mathrm{PM}_{2.5}$ annual limit value $\left(25 \mathrm{\mu g} \mathrm{m}^{-3}\right.$ in 2015; European Directive 2008/50/EC) and the recommendations of the World Health Organization $\left(\mathrm{PM}_{2.5}\right.$ annual average of $10 \mu \mathrm{g} \mathrm{m}^{-3}$; WHO, 2006) at urban (e.g. Bologna, $35.8 \mu \mathrm{g} \mathrm{m}^{-3}$ ) and regional background sites (e.g. Ispra, $32.2 \mu \mathrm{g} \mathrm{m}^{-3}$; Putaud et al., 2010). Consequently, $\mathrm{PM}_{2.5}$ impacts on human health are among the most severe in Europe (EC, 2005), while impacts on the local radiative forcing are substantial (Clerici and Mélin, 2008; Ferrero et al., 2014; Putaud et al., 2014b). Effective PM abatement strategies are thus needed in the Po Valley and require an in-depth knowledge of the chemical composition of fine PM to quantify its sources and the atmospheric processes leading to its secondary formation.

In this region, high levels of fine aerosol are mostly due to the conjunction of (i) high pollutant emissions related to industrial, transport, biomass burning and agricultural activities - the Po river basin hosting $37 \%$ of the Italian industries, $55 \%$ of the livestock and contributing $35 \%$ of the Italian agricultural production (WMO et al., 2012) - and (ii) the specific geography and topography of this area - a flat basin surrounded by the Alps and Apennine Mountains dominated by weak winds that favour the accumulation of pollutants (Decesari et al., 2014; Kukkonen et al., 2005; Pernigotti et al., 2012). As a consequence, PM levels are high not only in urban areas but also at regional and rural background sites, which are key locations for investigating air pollution due to their distance from local sources and local phenomena. Measurements of fine PM mass and chemical composition at rural background sites are in addition specifically required in the current European directive on air quality (EU, 2008).

Previous studies have investigated the properties of fine aerosols at regional and rural background sites of the Po Valley region, including their chemical characteristics (e.g. Carbone et al., 2014; Putaud et al., 2002, 2010; Saarikoski et al., 2012), and their main sources (Belis et al., 2013; Gilardoni et al., 2011; Larsen et al., 2012; Perrone et al., 2012). Fine aerosols are primarily made of organics (30-80\% of fine PM mass, depending on the site and season studied), followed by ammonium nitrate and ammonium sulfate. Their main sources are fossil fuel, biomass burning and biogenic emissions to name a few. In addition, studies based on aerosol mass spectrometer measurements have been conducted in the Po Valley, with the aim of characterizing specific phenomena (e.g. fog events, cooking aerosols) or seasons (Dall'Osto et al., 2015; Decesari et al., 2014; Gilardoni et al., 2014; Saarikoski et al., 2012). In studies dealing with long time series (entire season or year), the chemical composition of fine aerosol is generally measured with a relatively low time resolution (typically $24 \mathrm{~h}$ ), thus preventing the study of its diurnal variation and short-lived chemical-physical processes. When documented with higher time resolutions (1 h or less), aerosol chemical composition and its sources are usually characterized for intensive campaigns of a few weeks only, hence not suitable to depict the seasonal or yearly air quality situation. In addition, the complexity of the fine organic fraction (e.g. Jimenez et al., 2009) requires state-of-the-art analytical and source apportionment (SA) techniques to identify organic aerosol (OA) chemical properties and sources.

The recently developed Aerosol Chemical Speciation Monitor (ACSM, Aerodyne Research Inc.; Ng et al., 2011a) is suitable to fill these gaps by providing the chemical composition of nonrefractory submicron aerosols (NR-PM ${ }_{1}$ ) with a time resolution of $30 \mathrm{~min}$, while operating on long timescales. Even though promising results have been recently reported (e.g. Budisulistiorini et al., 2014; Canonaco et al., 2013, 2015; Minguillón et al., 2015; Ng et al., 2011a; Petit et al., 2015; Ripoll et al., 2015; Sun et al., 2012), this technique is still novel and requires additional field deployment to test its consistency with independent methods for the monitoring of fine PM chemistry (e.g. filter measurements). In addition, information on the accuracy of this technique is of paramount importance given the growing number of ACSMs in Europe and the necessity to build a network of quality-assured and harmonized instruments for comparability of results - at present about 20 ACSMs are in operation in Europe (http://www.psi.ch/acsm-stations/ overview-full-period) within the frame of the EU ACTRIS network (Aerosols, Clouds, and Traces gases Research InfraStructure, http://www.actris.eu/). Moreover, by using receptor models, the apportionment of OA into its major components - hydrocarbon-like (HOA), biomass burning (BBOA) and oxygenated OA (OOA) - can be performed (Lanz et al., 2007; Zhang et al., 2011, and references therein).

In this study, we used an ACSM during 1 year with a 30 min time resolution at a regional background site of the Po Valley and performed subsequent SA analyses with the aim of (i) describing the high-time-resolved chemical composition of NR-PM 1 on a long timescale to better understand the physicochemical processes driving its temporal variations, (ii) apportioning the organic fraction into its main sources, (iii) identifying PM abatement strategies to efficiently reduce

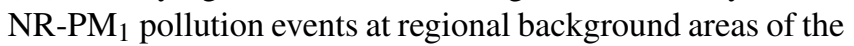
Po Valley, and (iv) assessing the atmospheric consistency of ACSM measurements when compared to independent analytical methods to evaluate its possible implementation in future European air quality networks. 


\section{Material and methods}

\subsection{Sampling site}

Measurements were conducted at the European Commission - Joint Research Centre (EC-JRC) Ispra site $\left(45^{\circ} 48^{\prime} \mathrm{N}\right.$, $8^{\circ} 38^{\prime} \mathrm{E} ; 217 \mathrm{~m}$ a.s.l.; Fig. S1 in the Supplement), which is part of the European Monitoring and Evaluation Programme (EMEP) measurement network (http://www.nilu.no/ projects/ccc/sitedescriptions/it/index.html) and the Global Atmosphere Watch (GAW) regional stations (http://www. wmo.int/pages/prog/arep/gaw/measurements.html). It is located on the northwest edge of the Po Valley region, $60 \mathrm{~km}$ northwest of the Milan urban area. It can be regarded as a "regional/rural background" site following the criteria recommended by the European Environment Agency (Larssen et al., 1999). For simplicity, the term "regional background site" will be used in the following although comparisons with rural background sites from other studies will also be reported. Further information on the study site can be found in Putaud et al. (2014b).

\subsection{Aerosol Chemical Speciation Monitor}

The recently developed ACSM (Aerodyne Research Inc., ARI) was used to measure the nonrefractory chemical composition (organics, nitrate, sulfate, ammonium, chloride) of submicron particles $\left(\mathrm{PM}_{1}\right)$ with a $30 \mathrm{~min}$ time resolution. The operating principle of the ACSM is similar to the widespread Aerodyne aerosol mass spectrometer (Canagaratna et al., 2007; Jayne et al., 2000), with the difference that the former does not inform on the size distribution of the chemical composition of NR-PM 1 . A full description of the ACSM can be found in Ng et al. (2011a). Briefly, an aerodynamic lens is used to focus submicron particles (50\% transmission range of $75-650 \mathrm{~nm}$; Liu et al., 2007), which are then vaporized in high vacuum, ionized by electron ionization (at $70 \mathrm{eV}$ ) and detected by a quadrupole mass spectrometer (Pfeiffer Vacuum Prisma Plus RGA). Two different quadrupole ACSMs (Q-ACSMs) were used in this study (from March 2013 to February 2014): Q-ACSM1 from 1 March to 18 August 2013 and Q-ACSM2 from 20 June 2013 to 28 February 2014. Note that Q-ACSM2 was not running from 3 November to 18 December due to its participation in the first inter-ACSM comparison exercise (Crenn et al., 2015). The reproducibility and consistency with independent measurements are discussed in Sect. 3.1. In the following, orthogonal regressions are reported unless otherwise stated.

Both ACSMs were operated with the latest Data Acquisition (DAQ 1.4.3.8 to 1.4.4.5) and Data Analysis (DAS 1.5.3.0 to 1.5.3.2) software (ARI, https://sites.google.com/ site/ariacsm/mytemplate-sw) available at the time of use, which are developed within Igor Pro 6.32A (Wavemetrics). Recommendations provided by Aerodyne (2010a, b) and Ng et al. (2011a) were followed for the operation, calibration and data analysis of the ACSMs. Ammonium nitrate calibrations were performed seasonally and used for the determination of experimental nitrate response factors (RFs) and ammonium relative ionization efficiencies (RIEs; see Sect. S1 in the Supplement for further details). Annual average and season-dependent experimental RF and RIE values were alternatively applied to assess whether the ACSM is stable over multi-seasonal periods (see Sect. 3.1 for results). Seasons are defined as spring (MAM), summer (JJA), autumn (SON) and winter (DJF). RIEs for organics, nitrate and chloride (1.4, 1.1 and 1.3, respectively) were taken from the literature (Canagaratna et al., 2007; Takegawa et al., 2005). RIE for sulfate was experimentally determined based on ammonium sulfate calibrations for ACSM2 and was taken from the literature for ACSM1 (see Sect. S1). Collection efficiencies (CEs) set as (i) a fixed 0.5 value (e.g. Budisulistiorini et al., 2013) or (ii) following the composition-dependent $\mathrm{CE}$ algorithm introduced by Middlebrook et al. (2012) were compared in order to determine the most appropriate CEs (see Sect. 3.1 for results).

\subsection{Additional analytical techniques}

Additional measurements routinely performed at the JRCIspra site are used in this study (see Putaud et al., 2014a, for a full description). $\mathrm{PM}_{2.5}$ was sampled on quartz fibre filters (Pall, 2500 QAT-UP) with a Partisol PLUS 2025 sampler equipped with a carbon honeycomb denuder operating at $16.7 \mathrm{~L} \mathrm{~min}^{-1}$ from 1 March 2013 to 28 February 2014 with daily filter changes at 08:00 UTC. Major ions $\left(\mathrm{NH}_{4}^{+}\right.$, $\mathrm{K}^{+}, \mathrm{NO}_{3}^{-}, \mathrm{SO}_{4}^{2-}$, etc.) are analysed by ion chromatography (Dionex DX 120 with electrochemical eluent suppression) after extraction in Milli-Q water (Millipore). Organic and elemental carbon (OC and EC, respectively) are quantified by a thermal-optical method (Sunset Laboratory Inc. dualoptical lab thermal-optical carbon aerosol analyzer) using the EUSAAR-2 protocol (Cavalli et al., 2010). Equivalent black carbon (BC) is measured by a multi-angle absorption photometer (MAAP, Thermo Scientific, model 5012) applying an absorption cross section of $6.6 \mathrm{~m}^{2} \mathrm{~g}^{-1}$ of equivalent $\mathrm{BC}$ at the operation wavelength of $670 \mathrm{~nm}$. Particle volume concentrations are determined with a homemade differential mobility particle sizer (DMPS) combining a Vienna-type differential mobility analyser (DMA) and a condensation particle counter (CPC, TSI 3010), following the European Supersites for Atmospheric Aerosol Research (EUSAAR) specifications for DMPS systems (Wiedensohler et al., 2012). Meteorological variables (temperature, pressure, relative humidity, precipitation, wind speed and direction) are determined from a weather transmitter WXT510 (Vaisala, Finland). Solar radiation is measured by a CM11 pyranometer (Kipp and Zonen, the Netherlands). 


\subsection{Apportionment of the organic fraction}

The organic fraction was apportioned using the positive matrix factorization approach (PMF; Lanz et al., 2007; Paatero and Tapper, 1994; Ulbrich et al., 2009; Zhang et al., 2011) by applying the Multilinear Engine 2 algorithm (ME-2, Paatero, 2000) implemented in the SoFi tool (v4.8, Canonaco et al., 2013; Crippa et al., 2014). Details on the theory and application of PMF and ME-2 can be found in the aforementioned studies. Briefly, PMF aims at factorizing an initial X matrix (representing the temporal variation of $m / z$ signals here) into two $\mathrm{F}$ and $\mathrm{G}$ matrices (representing factor profiles (FPs) and contributions, respectively), putting a constraint of nonnegativity on $\mathrm{F}$ and $\mathrm{G}$ matrices. Contrary to the classical program used to resolve PMF (e.g. PMF2, PMF3), ME-2 allows any element of the $\mathrm{F}$ and $\mathrm{G}$ matrices to be constrained with a certain degree of freedom. This ME-2 approach has been typically used to constrain full FPs (e.g. Amato et al., 2009; Crippa et al., 2014), specific elemental ratios (e.g. Sturtz et al., 2014) or specific species contribution (e.g. Crawford et al., 2005) in a given FP.

In our study, ME-2 is applied with and without constraining FPs, using the so-called $a$ value approach (Canonaco et al., 2013) in the former case, which can be described as follows:

$\left(f_{k, j}\right)_{\text {solution }}=\left(f_{k, j}\right)_{\text {reference }} \pm a\left(f_{k, j}\right)_{\text {reference }}$,

where $k$ and $j$ are the indexes for the factors and the species, respectively, $f_{k, j}$ is the element $(k, j)$ of the F matrix, the index "solution" stands for the PMF user solution, "reference" is the reference profile and " $a$ " is a scalar defined between 0 and 1 (e.g. applying an $a$ value of 0.10 lets $\pm 10 \%$ variability to our FP solution with respect to the reference FP). Following Crippa et al. (2014), we perform a sequence of runs with (i) unconstrained PMF, (ii) fixed HOA, (iii) fixed HOA and $\mathrm{BBOA}$, and (iv) fixed HOA, BBOA and cooking OA (COA) factors before selecting the most appropriate solution. Uncertainties are calculated using the DAS 1.5.3.0 version following the methodologies of Allan et al., (2003a) and Ulbrich et al. (2009). $m / z 12$ and 13 are removed for SA analysis since negative signals are observed most of the time. Reference factor profiles (RFPs) are taken from ambient deconvolved spectra from the aerosol mass spectrometry (AMS) spectral database (Ulbrich et al., 2015). HOA and BBOA profiles are taken from $\mathrm{Ng}$ et al. (2011c) (average of profiles from multiple studies) and COA from Crippa et al. (2013). Different $a$ values are tested (see Sect. 3.2) applying (i) relative standard deviations of averaged RFPs defined for every $m / z$ (i.e. assuming that the chosen averaged RFPs are representative of our dataset), (ii) recommendations of Crippa et al. (2014) based on the SA of 25 European AMS datasets and (iii) comparison with independent measurements (e.g. $\mathrm{NO}_{x}, \mathrm{CO}, \mathrm{BC}$ ). Solutions from two to eight factors are investigated in order to choose the appropriate number of factors (see Sects. S2 and 3.2).

\section{Quality assurance/quality control}

\subsection{Quality assurance/quality control of ACSM measurements}

Ammonium nitrate calibrations performed on each ACSM are shown in Fig. S2. $\mathrm{RF}_{\mathrm{NO}_{3}}$ and $\mathrm{RIE}_{\mathrm{NH}_{4}}$ do not present significant seasonal variability - e.g. for ACSM2, $\mathrm{RF}_{\mathrm{NO}_{3}}=4.7 \mathrm{E}-11 \pm 0.2 \mathrm{E}-11 \mathrm{~A} \cdot \mu \mathrm{g}^{-1} \mathrm{~m}^{3}$ - suggesting constant calibration factors may be used throughout the campaign. However, calibration factors exhibit substantial discrepancies between both ACSMs (e.g. $\mathrm{RF}_{\mathrm{NO}_{3}}$ of $2.5 \mathrm{E}-11$ and $4.7 \mathrm{E}-11 \mathrm{~A} \cdot \mu^{-1} \mathrm{~m}^{3}$ for ACSMs 1 and 2 , respectively), suggesting that instrument-specific factors are necessary. Applying constant and compositiondependent CEs does not lead to noticeable differences (e.g. for NR-PM $1: r^{2}=0.97$, slope $=1.00 \pm 0.00, y$ intercept $=0.10 \pm 0.03 \mu \mathrm{g} \mathrm{m}^{-3}, n=14842$ ) due to (i) low sampling line RH (e.g. typically below $30 \%$ for ACSM2) and (ii) few high-nitrate-content events (only $5 \%$ of data exhibits ammonium nitrate mass fractions $>40 \%$, defined as high by Middlebrook et al., 2012). The Middlebrook et al. (2012) algorithm is, however, preferred since slightly acidic aerosols are observed at the study site (on average sulfate plus nitrate against ammonium in $\mu$ eq $\mathrm{m}^{-3}: r^{2}=0.96$, slope $=1.21 \pm 0.00$, intercept $=0.01 \pm 0.00 \mu$ eq $\mathrm{m}^{-3}, n=14842$ ).

A comparison performed between the two ACSMs used in this study during a 2-month summer period is shown in Fig. S3. Very good correlations are observed for every chemical component $\left(0.91<r^{2}<0.98, n=1402\right.$, hourly average $)$ - chloride excluded - with slopes relatively close to one $(0.87<$ slopes $<1.42)$, indicating a fairly good comparability between both instruments. One of the two ACSMs also participated in the first-ever inter-ACSM comparison exercise performed between 13 different European Q-ACSMs during 3 weeks in Paris, France (Crenn et al., 2015). Satisfactory performances - defined by $z$ scores $<2-$ are reported for our instrument regarding every chemical component and NR$\mathrm{PM}_{1}$ mass, attesting the consistency of our measurements with other European sites.

Measurements performed by the ACSM and independent offline and online analytical techniques are compared in Fig. 1 and Table 1. An overall good agreement is found for every major components throughout the year (typically $r^{2}>0.8$ ), although discrepancies are observable for specific species and seasons. On the annual scale, a good agreement $\left(r^{2}=0.77, n=317\right)$ is found between organics from ACSM and OC from filter measurements in spite of expected filter sampling artefacts (Maimone et al., 2011; Turpin et al., 2000; Watson et al., 2009). Even better agreements are observed on a seasonal basis $\left(r^{2} \sim 0.9\right)$, with steeper slopes in summer compared with winter, which likely reflects the different degrees of oxygenation of organics among seasons (leading to different ratios of organic matter (OM) to OC). 

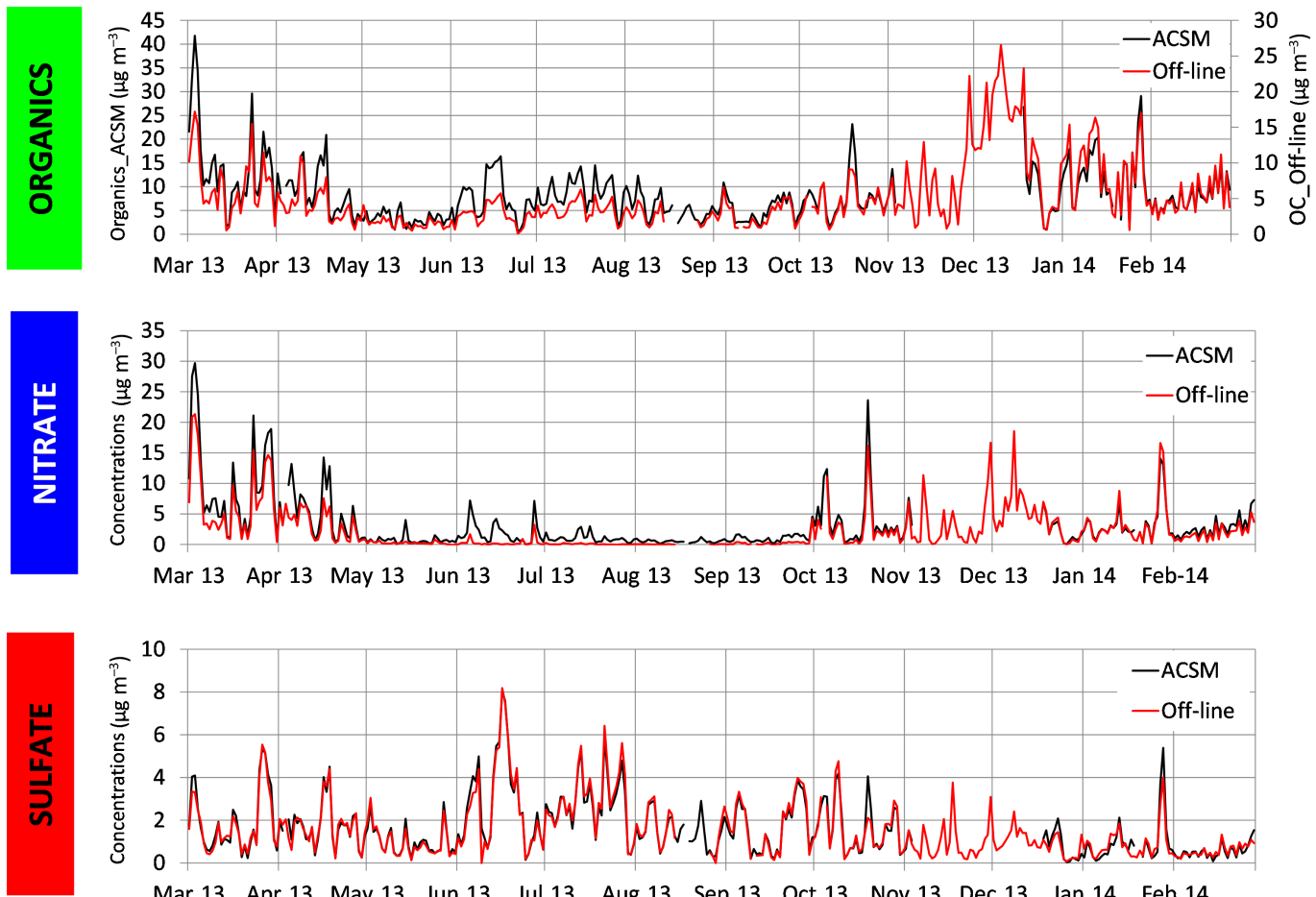

Mar 13 Apr 13 May 13 Jun 13 Jul 13 Aug 13 Sep 13 Oct 13 Nov 13 Dec 13 Jan 14 Feb 14
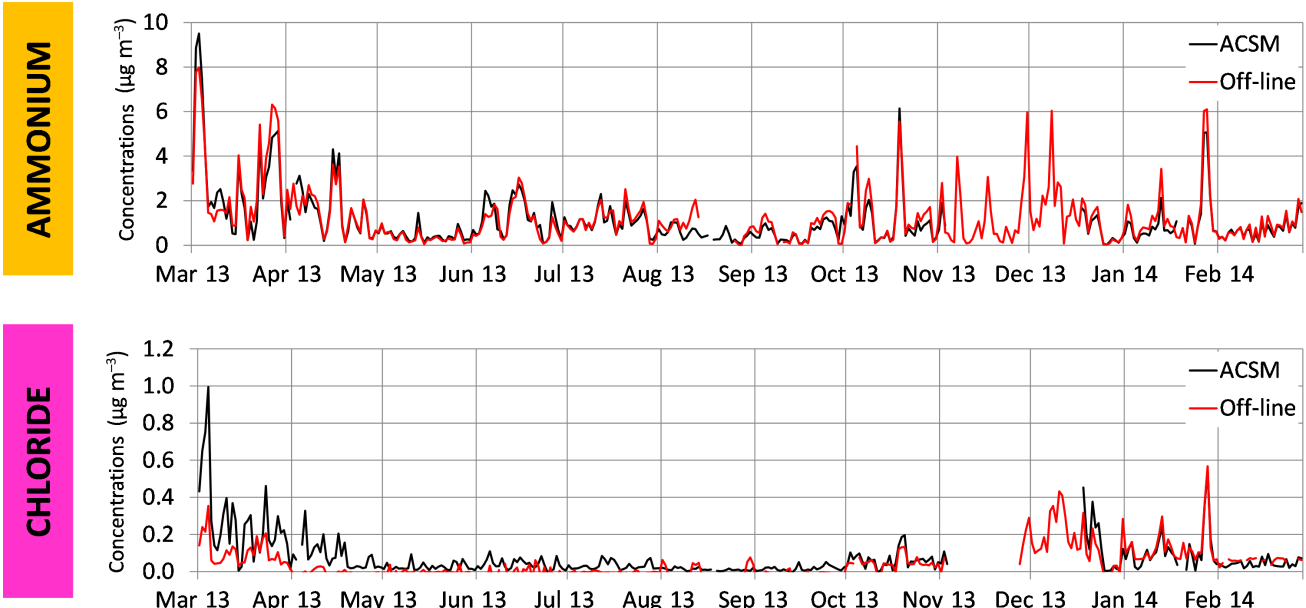

Mar 13 Apr 13 May 13 Jun 13 Jul 13 Aug 13 Sep 13 Oct 13 Nov 13 Dec 13 Jan 14 Feb 14

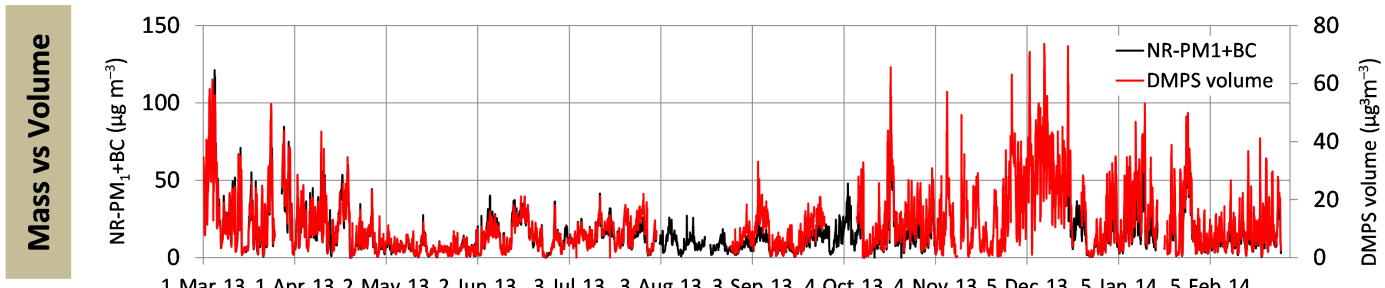

Figure 1. Comparison between measurements performed with the ACSM and other co-located analytical techniques. See Table 1 and Sect. 2.3 for more details. 
Table 1. Consistency of ACSM measurements: comparison between ACSM and independent analytical techniques using orthogonal regression analyses. Slopes and intercepts are indicated \pm uncertainties.

\begin{tabular}{|c|c|c|c|c|c|c|c|c|c|c|c|c|c|c|c|}
\hline & \multicolumn{5}{|c|}{$r^{2}$} & \multicolumn{5}{|c|}{ Slope } & \multicolumn{5}{|c|}{ Intercept } \\
\hline & $\mathrm{Sp}$ & $\mathrm{Su}$ & $\mathrm{Au}$ & Wi & An & $\mathrm{Sp}$ & $\mathrm{Su}$ & $\mathrm{Au}$ & Wi & An & $\mathrm{Sp}$ & $\mathrm{Su}$ & $\mathrm{Au}$ & Wi & An \\
\hline Org vs. OC & 0.91 & 0.90 & 0.86 & 0.92 & 0.77 & $2.18 \pm 0.07$ & $2.92 \pm 0.10$ & $1.87 \pm 0.09$ & $1.26 \pm 0.04$ & $1.72 \pm 0.04$ & $-0.29 \pm 0.37$ & $-1.07 \pm 0.32$ & $-0.28 \pm 0.36$ & $0.74 \pm 0.37$ & $0.61 \pm 0.25$ \\
\hline Nitrate & 0.95 & 0.53 & 0.96 & 0.92 & 0.91 & $1.37 \pm 0.03$ & $4.27 \pm 0.25$ & $1.28 \pm 0.03$ & $0.86 \pm 0.03$ & $1.28 \pm 0.02$ & $0.42 \pm 0.18$ & $0.64 \pm 0.11$ & $0.48 \pm 0.10$ & $0.62 \pm 0.11$ & $0.48 \pm 0.09$ \\
\hline Sulfate & 0.96 & 0.97 & 0.92 & 0.86 & 0.95 & $1.05 \pm 0.02$ & $0.98 \pm 0.02$ & $0.96 \pm 0.04$ & $1.38 \pm 0.06$ & $1.00 \pm 0.01$ & $-0.01 \pm 0.04$ & $0.02 \pm 0.06$ & $0.04 \pm 0.07$ & $-0.25 \pm 0.06$ & $0.00 \pm 0.03$ \\
\hline Ammonium & 0.92 & 0.70 & 0.91 & 0.95 & 0.90 & $1.03 \pm 0.03$ & $1.00 \pm 0.06$ & $0.93 \pm 0.04$ & $0.81 \pm 0.02$ & $0.99 \pm 0.02$ & $-0.04 \pm 0.07$ & $-0.04 \pm 0.07$ & $-0.12 \pm 0.05$ & $0.03 \pm 0.03$ & $-0.08 \pm 0.03$ \\
\hline Chloride & 0.75 & 0.00 & 0.59 & 0.78 & 0.52 & $2.68 \pm 0.13$ & $-0.13 \pm 0.09$ & $0.68 \pm 0.06$ & $1.13 \pm 0.07$ & $1.75 \pm 0.06$ & $0.04 \pm 0.01$ & $0.03 \pm 0.00$ & $0.04 \pm 0.00$ & $-0.02 \pm 0.01$ & $0.02 \pm 0.01$ \\
\hline Mass vs. volume & 0.87 & 0.82 & 0.88 & 0.85 & 0.81 & $1.91 \pm 0.01$ & $1.95 \pm 0.02$ & $1.45 \pm 0.01$ & $1.34 \pm 0.01$ & $1.63 \pm 0.01$ & $-1.16 \pm 0.19$ & $-1.36 \pm 0.18$ & $-2.45 \pm 0.19$ & $-0.11 \pm 0.20$ & $-1.09 \pm 0.11$ \\
\hline
\end{tabular}

However, these slopes cannot be directly regarded as the $\mathrm{OM}$-to-OC ratios due to (i) differences in size fractions between both methods ( $\mathrm{PM}_{1}$ for ACSM and $\mathrm{PM}_{2.5}$ for filter measurements) and (ii) uncertainties related to $\mathrm{RIE}_{\mathrm{Org}}$ for ACSM measurements (Budisulistiorini et al., 2014; Ripoll et al., 2015). An estimation of the OM-to-OC ratio for submicron organics applying the methodology described by Canagaratna et al. (2015) is discussed in Sect. 4.2. Good correlations are observed for nitrate during all seasons $\left(r^{2}>0.9\right)$ but summer $\left(r^{2}=0.5\right)$, which is most likely related to enhanced evaporative losses of ammonium nitrate from filter during the latter season (Chow et al., 2005; Schaap et al., 2004). Slopes range from 0.9 to 1.4 - summer excluded which is comparable to what is reported elsewhere (Budisulistiorini et al., 2014; Crenn et al., 2015; Ripoll et al., 2015). Very good correlations are observed for sulfate in every season $\left(r^{2}=0.9-1.0\right)$ with slopes close to $1(0.9-1.1$, winter excluded), consistent with its presence in the submicronic size fraction and its low volatility leading to the minimization of sampling artefacts. Note that discrepancies have been reported when comparing sulfate measured by the ACSM (Petit et al., 2015) or the AMS (Zhang, 2005) with independent measurements. Our results suggest that ammonium sulfate calibrations should be performed to experimentally determine sulfate RIEs, which appear to be instrument specific but stable over several months. Although aerosols are slightly acidic on average at the study site, ammonium mostly neutralizes nitrate and sulfate throughout the campaign and thus exhibits behaviour in between the two latter compounds. Higher uncertainties are associated with chloride from filter quantification, resulting in no agreement with ACSM measurements in summer when the concentrations are the lowest $\left(r^{2}=0.00\right)$ and fairly good agreement during the other seasons $\left(r^{2}=0.64-0.77\right)$. The high slope observed for ACSM1 (e.g. 2.1 during spring) compared to the fairly good slopes observed for ACSM2 (0.7-1.1) suggests that chloride RIE might be instrument specific and require appropriate calibrations for its accurate quantification (see also Riffault et al., 2013, on this topic).

The sum of NR-PM 1 components and $\mathrm{BC}$ has been compared to the volume concentration of $\mathrm{PM}_{1}$. Good agreement is found between both variables $\left(r^{2}>0.8\right)$, giving further confidence on the consistency of our ACSM measurements. The annual average particle density estimated from this com- parison (i.e. slope) is 1.6, which is typical of ambient aerosol particles densities (1.5-1.9 in Hand and Kreidenweis, 2002; Hu et al., 2012; McMurry et al., 2002; Pitz et al., 2003, 2008). The higher densities observed during spring and summer (1.9-2.0) than autumn and winter (1.3-1.5) are likely due to the enhanced contribution of secondary aerosol and aged particles during the former period (Pitz et al., 2008).

\subsection{Quality assurance/quality control of organic source apportionment}

First, during the aforementioned inter-ACSM comparison study (Crenn et al., 2015), source apportionment of organics was performed based on data from 13 Q-ACSMs (Fröhlich et al., 2015), including one ACSM used in the present study. Satisfactory performances $(z$ scores $<2)$ are reported for our ACSM using a similar approach as adopted in this study. This result demonstrates that our instrument and the associated data treatment, including the source apportionment modelling, are capable of accurately identifying and quantifying OA sources.

\subsubsection{Model configurations}

Regarding our specific study, the configuration applied to reach the optimal SA of organics is thoroughly discussed in Sect. S2 (constrained FPs, number of factors, $a$ values and integration-period durations). Briefly, constraining both HOA and BBOA factors result in satisfactory solutions with relevant FPs, time series and daily cycles. Other configurations (e.g. unconstrained factors) lead to unsatisfactory results with high seed variability, mixing of factors or absence of key fragments in identified profiles (e.g. absence of $m / z 43$ and 44 in BBOA contrary to what is reported in Heringa et al., 2011, Fig. S4). Solutions applying different number of factors are investigated. Three factors (HOA, BBOA and OOA) are retained during spring, autumn and winter, whereas two factors (HOA and OOA) are most suitable during summer. A lower number of factors results in a mixing of them, whereas a higher number generates additional factors - e.g. semi-volatile OOA (SV-OOA) during summer, OOA-BBOA during autumn - which are not satisfactory - e.g. missing fragments or poor correlations with external data (see Table S1). BBOA cannot be clearly iden- 
tified during summer; i.e. in this season agricultural waste burning contributions are estimated to be minor (maximum $3-4 \%$ of OA, Sect. S2). Note that COA could not be evidenced, likely due to the type of site studied (regional background) and the lower sensitivity, time and mass-to-charge resolution of the ACSM compared to classical AMS instruments (further discussed in Sect. S2; see also Dall'Osto et al., 2015, on this subject). Uncertainties associated with factor contributions are estimated by performing sensitivity tests on $a$ values, which are regarded as the most subjective input parameters. Five scenarios putting very low to very high constraints on the reference FPs have been defined (see Table S2). Comparable solutions in terms of relative contributions (Fig. S5) and agreement with independent measurements (Table S2) are found when applying low to high constraints following the empiric recommendations of Crippa et al. (2014). Unsatisfactory solutions are generally reached under the extreme scenarios (fully fixed FPs and $\mathrm{m} / z$ specific standard deviations of RFPs). We decided to apply low constraints (i.e. $a$ values of 0.1 and 0.5 for HOA and BBOA, respectively) to let as much freedom as possible to our FPs while remaining in the range of plausible solutions. SA was performed on 3-month, 6-month and 1year datasets. Although comparable solutions are found for each configuration (number of factors, factor profiles, diurnal cycles, comparisons with external data), applying SA on seasonal datasets was preferred since (i) the seasonal variability of FPs is captured and (ii) questionable results are observed in summer for 6-month and 1-year configurations (see Sect. S2). When comparing the sum of OA factor concentrations and measured $\mathrm{OA}$ on the annual scale, OA is very well modelled $\left(r^{2}=0.97\right.$, slope $=0.98 \pm 0.00$, intercept $=0.1 \pm 0.0 \mu \mathrm{g} \mathrm{m}^{-3}, n=14842$ ).

\subsubsection{Model optimal solution}

Factor profiles, contributions and daily cycles of the optimal SA solution are presented in Fig. 2. Independent FPs and time series are found for each season, which is a prerequisite for having reliable SA solutions. HOA is identified during every season and exhibits a profile dominated by alkyl fragments such as $m / z 55$ (from the $\mathrm{C}_{n} \mathrm{H}_{2 n-1}^{+}$ion series) and $m / z 57$ (from $\mathrm{C}_{n} \mathrm{H}_{2 n+1}^{+}$ion series; $\mathrm{Ng}$ et al., 2011c). Its relative contribution is characteristic of traffic emissions, exhibiting a peak in the morning and higher contributions during weekdays than weekends (e.g. averages of 14 and $9 \%$, respectively, in autumn; Fig. S6). BBOA is found during every season except summer and has a profile similar to that of $\mathrm{HOA}$, except for the high contribution of $m / z 60\left(\mathrm{C}_{2} \mathrm{H}_{4} \mathrm{O}_{2}^{+}\right)$ and $73\left(\mathrm{C}_{3} \mathrm{H}_{5} \mathrm{O}_{2}^{+}\right)$, which have been suggested as biomass burning markers (Lee et al., 2010, and references therein). A distinct daily cycle with higher contributions during nighttime than daytime is observed, in addition to higher contributions during weekends than weekdays (e.g. averages of 24 and $21 \%$, respectively, in spring; Fig. S6), consistent with residential heating emissions. The low BBOA concentrations modelled during late spring and early autumn, as well as the small increased contribution observed during the morning also suggest residential heating emissions. OOA is identified thanks to the predominant contribution of $m / z 44\left(\mathrm{CO}_{2}^{+}\right)$ and $43\left(\mathrm{C}_{2} \mathrm{H}_{3} \mathrm{O}^{+}\right)$. The higher contribution of $f_{44}$ (defined as $\mathrm{m} / \mathrm{z} 44$ to total organic signal; $0.17-0.23$ depending on seasons) with respect to $f_{43}$ (defined similarly; 0.05-0.09) suggests that this OOA factor is highly oxidized and presents low-volatile OOA (LV-OOA) rather than SV-OOA characteristics (see Jimenez et al., 2009, and Zhang et al., 2011, for definitions of these components). This statement is supported by very good correlations $\left(r^{2}=0.96-0.99\right)$ found between our unconstrained OOA profiles and the average LV-OOA profile reported by $\mathrm{Ng}$ et al. (2011c) from six AMS studies. Interestingly, our OOA profiles present slight seasonal differences that likely reflect changes in source contributions and/or physical-chemical processes in this factor. For instance, $f_{60}$ in OOA profiles is enhanced in winter (0.014) compared with other seasons (0.001-0.004), which suggests that biomass burning contributes to this factor during the aforementioned season, consistent with different studies reporting $f_{60}$ in secondary OA from biomass burning (e.g. $\mathrm{Cu}-$ bison et al., 2011; Heringa et al., 2011; see Sect. S2). Note that the mass spectral resemblance of primary humic-like substances to LV-OOA might also partly explain this observation (e.g. Young et al., 2015), i.e. that a small fraction of primary OA is found in this factor. Daily cycles are comparable for all seasons with a bimodal pattern characterized by a small peak during night-time and a prominent peak during daytime. The latter peak suggests that a fraction of (LV-) OOA could be locally rather than regionally produced on the timescale of few hours only, likely due to enhanced photochemical activities during daytime. The former peak could be due to (i) the condensation of highly oxygenated semivolatile material favoured by night-time thermodynamic conditions or (ii) a contribution of SV-OOA in our OOA factor, which is generally dominated by LV-OOA. The absence of an $f_{44}$ night-time peak (Sect. 4.2) suggests that the second assumption is more probable implying that both SV-OOA and LV-OOA influence our OOA factor.

\subsubsection{Time series comparisons}

Comparisons between our OA factors, $m / z$ tracer and independent species time series are shown in Table 2. OOA time series show very good agreement with Org_43 (organic signal at $m / z$ 43) and Org_44 $\left(r^{2}>0.8\right.$ and 0.9 , respectively) and relatively good agreement with secondary inorganic species (e.g. $r^{2} \geq 0.5$ for ammonium), indicating that this factor can be regarded as a surrogate for secondary organic aerosols. Comparisons with sulfate (a low-volatility species) and nitrate (a semi-volatile species) confirm that our OOA factor might be a mix of SV-OOA and LV-OOA, since better agreement is found with one or the other compound 

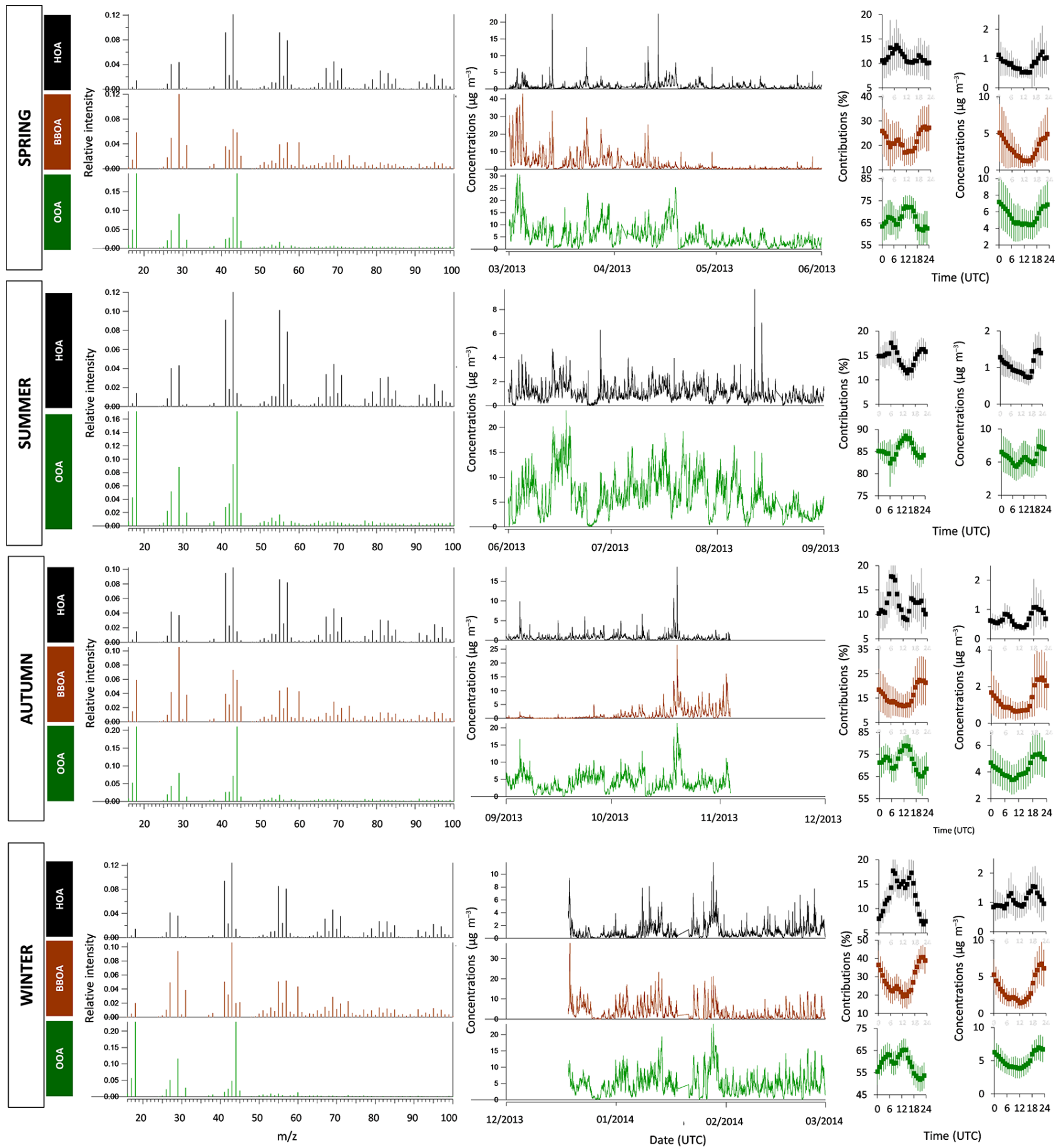

Figure 2. Organic source apportionment presented by season: factor profiles (left), time series (middle) and daily cycles (right, error bars represent 1 standard deviation). Seasons are defined as spring (MAM), summer (JJA), autumn (SON) and winter (DJF).

depending on the season studied. BBOA exhibits very good coefficients of determination when compared with its presumable fragment tracers Org_60 and Org_73 $\left(r^{2}>0.97\right)$, giving further confidence on its appropriate quantification. Good correlations are generally found between BBOA and $\mathrm{BC}\left(r^{2} \geq 0.5\right.$, except for summer) indicating that a large pro- portion of BC stems from biomass burning, consistent with previous findings at the study site (Gilardoni et al., 2011, from EC measurements). A good agreement is also observed with $\mathrm{CO}\left(r^{2} \geq 0.7\right)$, as already reported in the Alpine valleys (e.g. Gaeggeler et al., 2008). HOA is not as well correlated with external data or specific $m / z$, which could be related to 
Table 2. Comparison (coefficient of determination, $r^{2}$ ) between SA factors, organic $m / z$ tracers and independent species time series. BC stands for black carbon; Org_ $i$ stands for organic signal at $m / z i(i=43,44,60,67,73,81)$.

\begin{tabular}{|c|c|c|c|c|c|c|c|c|c|c|c|c|c|c|c|}
\hline & \multicolumn{5}{|c|}{$\mathrm{HOA}$} & \multicolumn{5}{|c|}{ BBOA } & \multicolumn{5}{|c|}{ OOA } \\
\hline & Org_67 & Org_81 & $\mathrm{NO}_{x}$ & $\mathrm{CO}$ & BC & Org_60 & Org_73 & $\mathrm{NO}_{x}$ & $\mathrm{CO}$ & $\mathrm{BC}$ & Org_43 & Org_44 & $\mathrm{NH}_{4}$ & $\mathrm{SO}_{4}$ & $\mathrm{NO}_{3}$ \\
\hline Spring & 0.60 & 0.55 & 0.03 & 0.08 & 0.28 & 0.99 & 0.97 & 0.32 & 0.81 & 0.70 & 0.88 & 0.94 & 0.76 & 0.43 & 0.77 \\
\hline Summer & 0.90 & 0.91 & 0.07 & 0.40 & 0.52 & & & - & & & 0.97 & 0.94 & 0.54 & 0.60 & 0.19 \\
\hline Autumn & 0.63 & 0.61 & 0.07 & 0.10 & 0.24 & 0.99 & 0.97 & 0.06 & 0.68 & 0.47 & 0.82 & 0.92 & 0.47 & 0.53 & 0.38 \\
\hline Winter & 0.58 & 0.57 & 0.34 & 0.33 & 0.39 & 0.98 & 0.97 & 0.20 & 0.66 & 0.63 & 0.80 & 0.99 & 0.50 & 0.39 & 0.66 \\
\hline
\end{tabular}

(a)

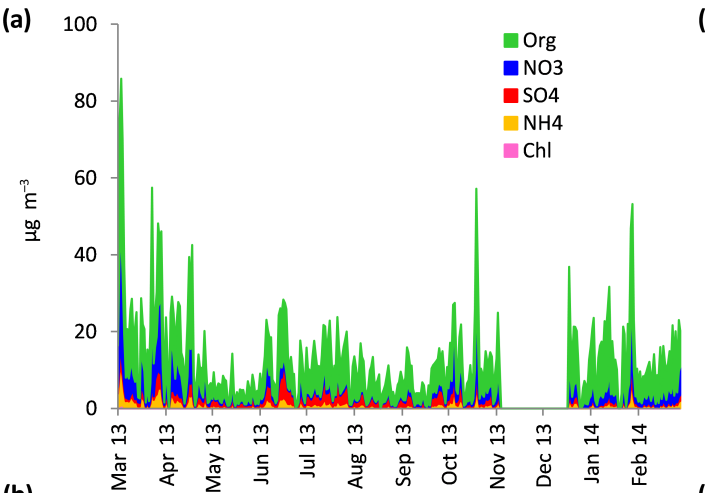

(b)

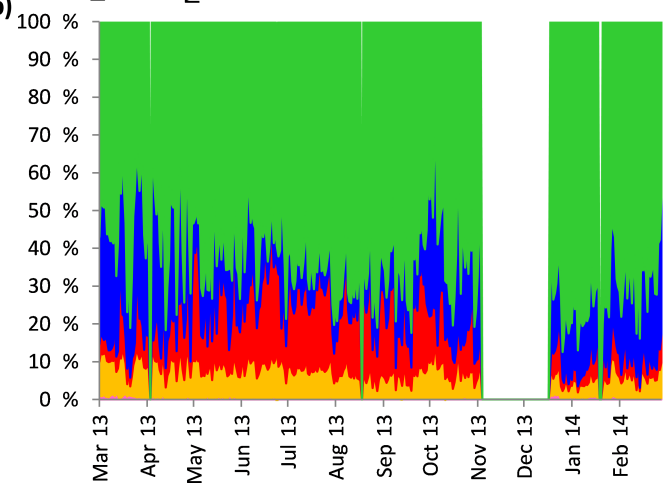

(c)

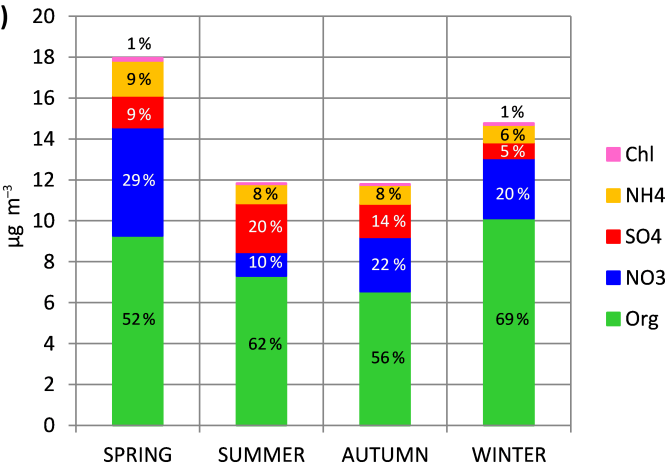

(d)

Org

$\mathrm{SO} 4$

NH4

Chl

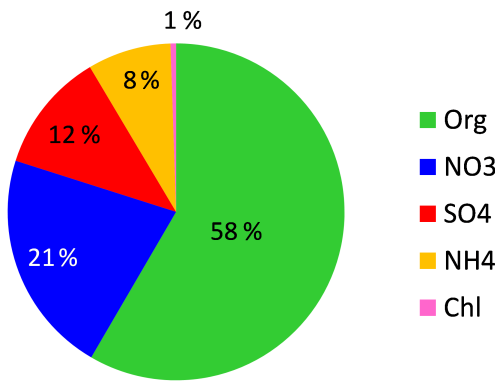

$\left[\mathrm{NR}-\mathrm{PM}_{1}\right]_{\mathrm{annual}}=14.2 \mu \mathrm{g} \mathrm{\textrm {m } ^ { - 3 }}$

Figure 3. Overview of the chemical composition of NR-PM 1 at Ispra (Po Valley, Italy): daily absolute (a) and relative (b) chemical composition; seasonal (c) and annual (d) averages.

(i) the absence of clear $m / z$ tracers for this factor due to similarities with BBOA profile, (ii) the absence of clear external tracers due to co-emissions by fossil fuel and biomass burning activities of $\mathrm{BC}, \mathrm{CO}$ and $\mathrm{NO}_{x}$ and (iii) possible uncertainties associated with the apportionment between HOA and BBOA. The first two assumptions are supported by the better agreement observed between HOA and $m / z$ fragments or independent data during summer (e.g. $r^{2}=0.52, n=2208$ between HOA and BC) and specific months (e.g. May, September), when biomass burning contributions are negligible. Although uncertainties associated with the accurate apportionment of HOA and BBOA cannot be excluded (e.g. due to rotational ambiguity), several factors evidence the robustness of the results and indicate that a mixing of both factors is unlikely, since HOA and BBOA present (i) independent factor time series during all seasons $\left(r^{2}=0.1-0.2\right)$, (ii) distinct and relevant daily cycles and (iii) no significant $a$ value variability.

\section{Results and discussion}

The meteorological representativeness of this 1-year measurement is assessed by comparing the solar irradiation, precipitation and temperature monthly averages to the ones measured during 1990-2010 at the study site (Fig. S7). Comparable seasonal averages are generally found in our study and during the bidecadal reference period. Nevertheless, compared to 1990-2010, spring 2013 was rainier, summer 2013 slightly warmer and sunnier and winter 2013-2014 rainier. Further information regarding the representativeness of measurements performed at the study site during the year 2013 can be found in Putaud et al. (2014a). 


\subsection{Chemical composition of NR-PM}

An overview of the chemical composition of NR-PM 1 retrieved during this campaign is shown in Fig. 3. The annual averaged NR-PM ${ }_{1}$ mass reported here $\left(14.2 \mu \mathrm{g} \mathrm{m}^{-3}\right)$ ranges amongst the highest NR-PM 1 levels (7th out of 41 sites) reported at rural and urban downwind sites in Europe (Crippa et al., 2014) and worldwide (Jimenez et al., 2009; Zhang et al., 2007, 2011). Please note that these previous studies are based on typically 1 month of measurements in different seasons. It is comparable to NR-PM 1 levels reported during specific campaigns in the urban areas of New York City (USA, $12 \mu \mathrm{g} \mathrm{m}^{-3}$; Weimer et al., 2006), Tokyo (Japan,

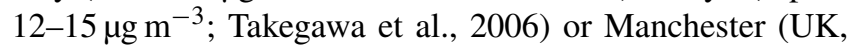
$14 \mu \mathrm{g} \mathrm{m}^{-3}$; Allan et al., 2003a, b). Our annual average NR$\mathrm{PM}_{1}$ mass is higher than the $10 \mu \mathrm{g} \mathrm{m}^{-3}$ guideline given by the World Health Organization for the annual average $\mathrm{PM}_{2.5}$ mass (including refractory and nonrefractory compounds; WHO, 2006). After similar conclusions have been drawn for $\mathrm{PM}_{2.5}$ and $\mathrm{PM}_{10}$ size fractions (Putaud et al., 2010), the Po Valley appears to be one of the most polluted regions in Europe with regard to NR-PM 1 levels this time. Submicron aerosol particles are mostly made of organics $(58 \%)$, nitrate $(21 \%)$, sulfate $(12 \%)$ and ammonium (8\%; Fig. 3). The predominance of organics is typical of urban downwind sites (e.g. average of $52 \%$ reported in Zhang et al., 2011). However, the noticeable proportion of nitrate is characteristic of urban sites (18\% in Zhang et al., 2011), which likely reflects the substantial influence of anthropogenic activities emissions at our regional site. As a result, sulfate exhibits particularly low contributions at the study site compared with other locations (generally $>20 \%$ in Zhang et al., 2011).

NR-PM 1 levels present a clear seasonality with higher levels during spring $\left(\sim 18 \mu \mathrm{g} \mathrm{m}^{-3}\right)$ and winter $\left(\sim 15 \mu \mathrm{g} \mathrm{m}^{-3}\right)$ compared with summer and autumn $\left(\sim 12 \mu \mathrm{g} \mathrm{m}^{-3}\right)$. Higher levels were expected during cold months due to enhanced biomass burning emissions and lower boundary layer heights (BLHs), as previously observed at the study site (Putaud et al., 2013). Expected seasonal variations of the chemical composition of NR-PM 1 are observed, with (i) higher nitrate contributions during the cold season which favours its partitioning in the condensed phase (Clegg et al., 1998), (ii) higher sulfate contributions during summer, which can e.g. be associated with enhanced photochemical production (Seinfeld and Pandis, 2006) and lower amount of rainout (Fig. S7), and (iii) relatively stable contributions for ammonium (mainly neutralizing the two previous species) and organics (discussed later on).

A focus will now be made on daily cycles of the chemical composition of NR-PM 1 (Fig. 4), displayed for the first time during the four seasons in the Po Valley, thanks to the high time resolution and stability of the ACSM. On the annual scale, daily cycles of NR-PM 1 levels are characterized by significantly higher concentrations during night-time than daytime, likely due to lower BLH, higher wood burn- ing emissions (during cold seasons) and lower temperatures favouring the partitioning of semi-volatile inorganic (mainly ammonium nitrate) and organic material in the condensed phase, to name a few. A distinct peak is, however, observed around noon, probably caused by enhanced photochemical production of secondary organic compounds and increased BLH favouring downward mixing of advected pollution, especially during summer (Fig. 4; Decesari et al., 2014). Note that this annual daily pattern is the combination of distinct daily cycles varying with the season studied (Fig. 4). In terms of relative chemical composition, organics dominate NR-PM ${ }_{1}$ mass independently of the time of the day, with median contributions ranging from $\sim 60$ to $70 \%$. Nitrate exhibits higher contribution during night-time due to its abovementioned semi-volatile nature. Sulfate shows unexpected daily cycles with significantly different $(99.99 \%$ confidence level) relative contributions - and absolute concentrations - during daytime ( $\sim 15 \%$ of NR-PM $\mathrm{PM}_{1}$ mass around noon) compared to night-time ( $\sim 10 \%$ around midnight, Fig. 4$)$, although its formation was expected to occur mainly over longer timescales (i.e. days) in cloud droplets (Ervens et al., 2011). This observation could be due to (i) local production of sulfate with increased photochemical production around noon at the study site and/or (ii) diurnal changes of the atmospheric stratification in the Po Valley as described by Saarikoski et al. (2012) and Decesari et al. (2014), enhancing aged particle contribution during the middle of the day and the afternoon. Nonrefractory chloride (mostly $\mathrm{NH}_{4} \mathrm{Cl}$, Huang et al., 2010) exhibits very low contributions independently of the hour of the day (medians below $0.5 \%$ of NR-PM $\mathrm{P}_{1}$ mass) but with a slight increase at night, which is likely due to its presumable semi-volatile nature here.

\subsection{Focus on organic aerosols}

An overview of the contribution of HOA, BBOA and OOA to OA is shown in Fig. 5. On the annual average, the organic fraction is dominated by the secondary component (OOA, $66 \%)$. Although this OOA contribution is substantial, higher proportions are generally reported at rural and urban downwind sites worldwide (90 and $82 \%$ of OA on average, respectively; Zhang et al., 2011). This lower relative contribution of OOA is related to the higher contribution of (primary) BBOA in our study (23\% of OA on the annual average) compared to the previous ones. Considerable contributions of BBOA are explained by the specific location of the study site in the vicinity of the Alps, where biomass burning is a major contributor to OA (Belis et al., 2011; Herich et al., 2014; Lanz et al., 2010). Biomass burning emissions hence substantially affect OA levels on the annual scale here. The contribution of HOA is comparatively smaller (11\%), indicating that despite the expected large contributions of fossil fuel emissions (i.e. traffic and industrial emissions), those are not the major sources of primary OA at the study site. However, it is likely that fossil fuel emissions of volatile or- 

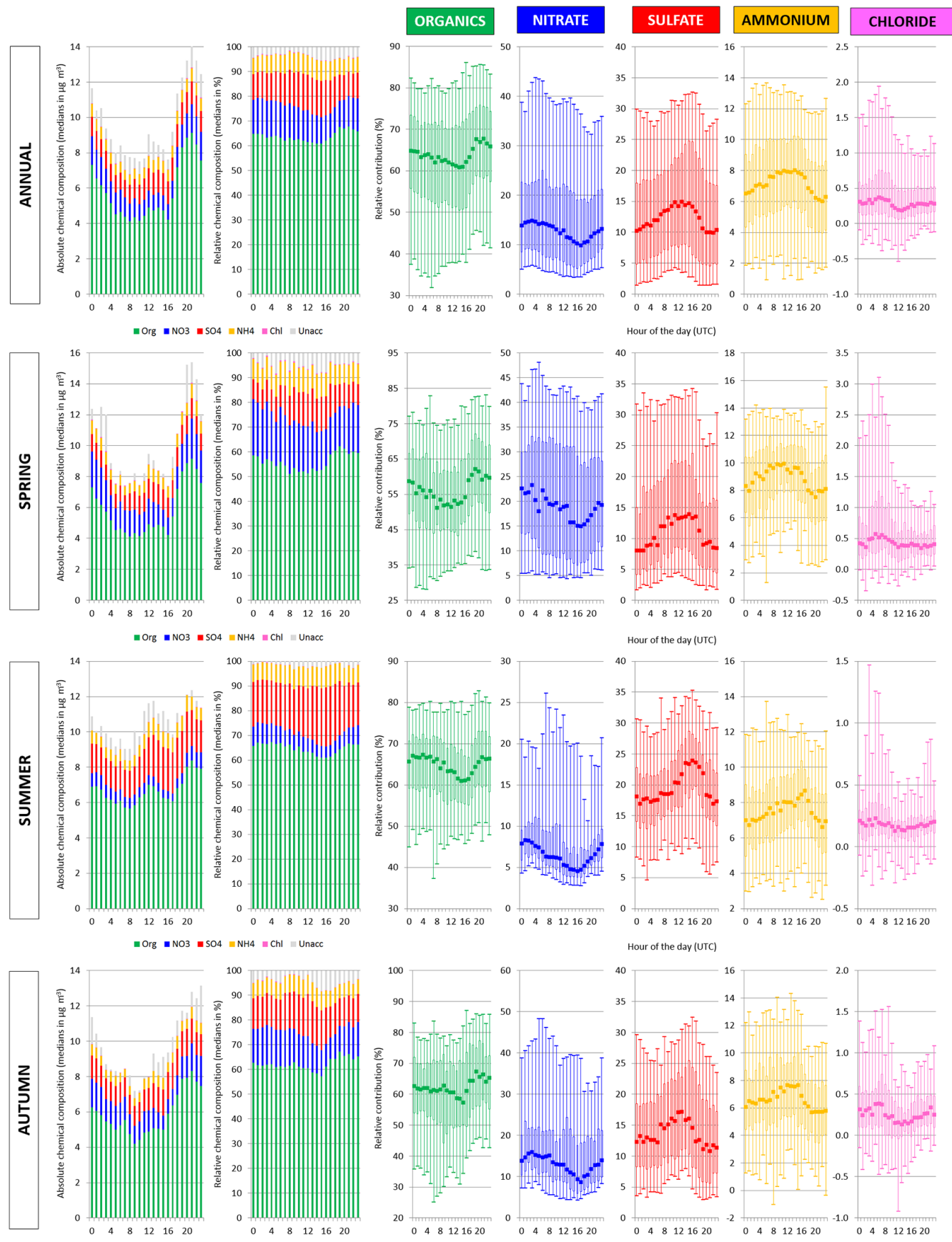

Hour of the day (UTC)

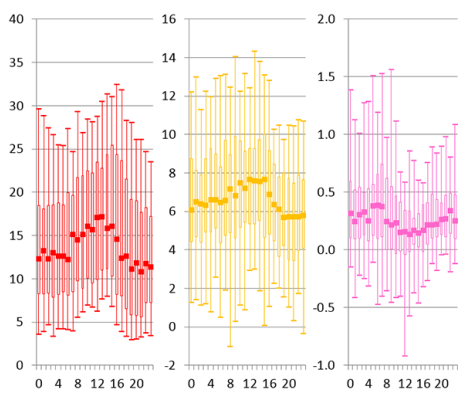

= Org $\boldsymbol{\text { NO3 }} \| \mathrm{SO}=\mathrm{NH} 4=\mathrm{CHl}=$ Unacc
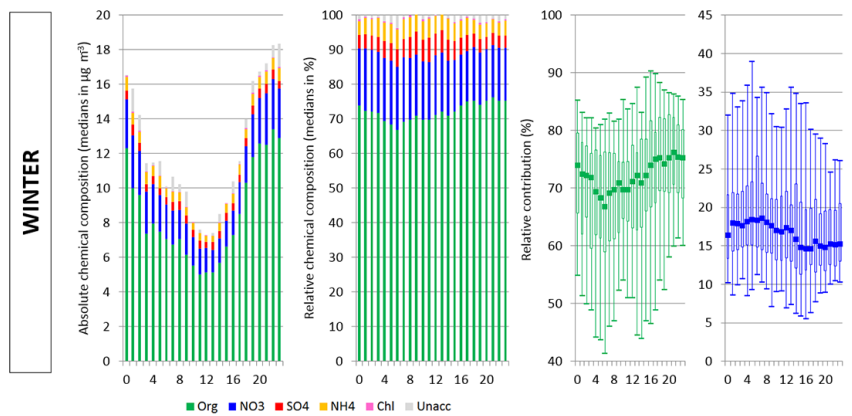

Hour of the day (UTC)

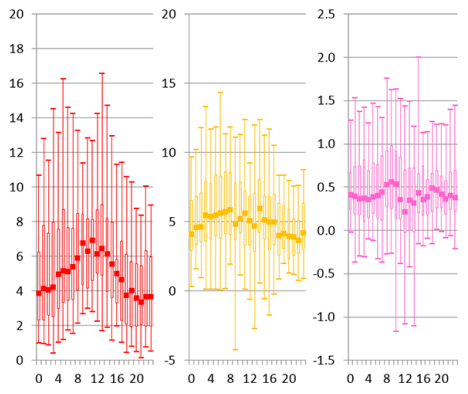

Figure 4. Daily cycles of NR-PM 1 chemical composition on the annual and seasonal scales. Unacc: unaccounted mass. Whisker plots are constructed from the 5th, 25th, 50th, 75th and 95th percentiles. 
(a)

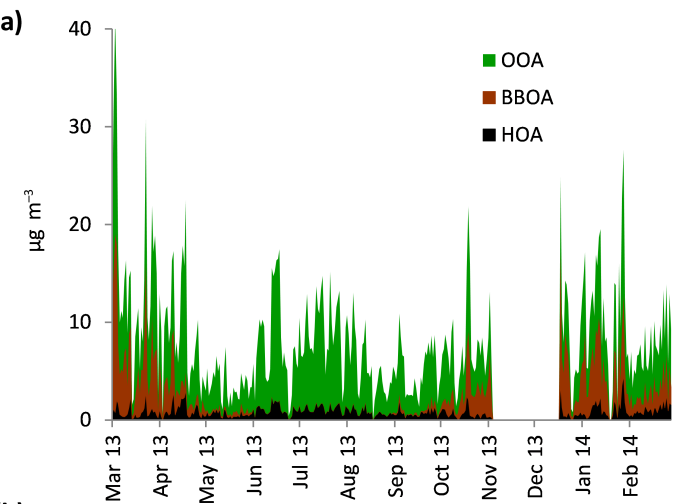

(b)

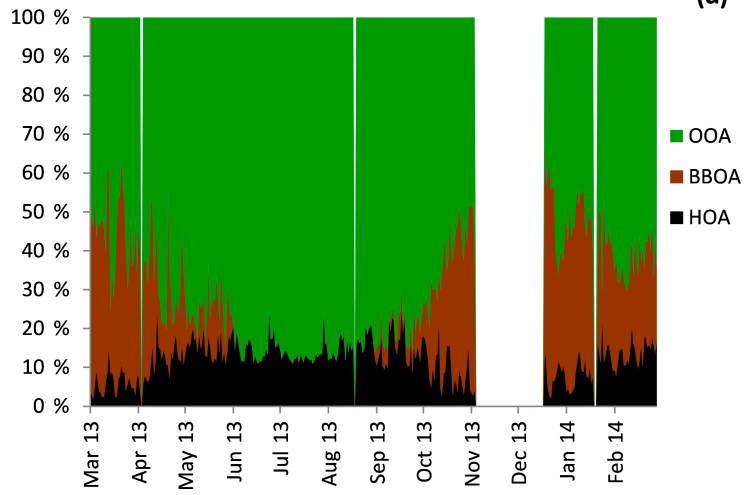

(c)

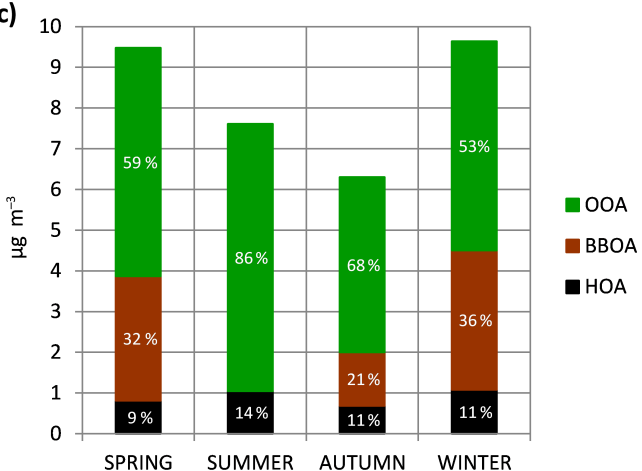

(d)

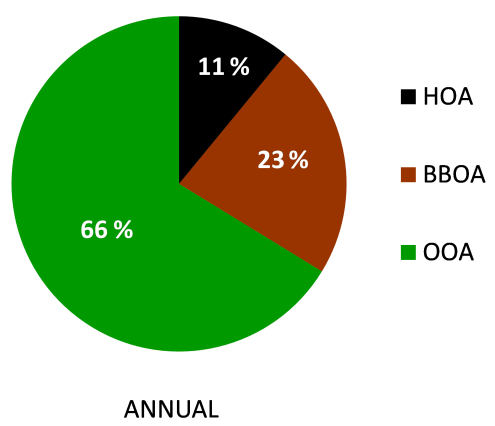

Figure 5. Overview of HOA, BBOA and OOA contributions to organic aerosols; see legend in Fig. 3.

ganic compounds (VOCs) - which are OOA precursors contribute to our OOA levels as reported elsewhere (Gentner et al., 2012; Volkamer et al., 2006). At the study site, Gilardoni et al. (2011) previously estimated on the basis of ${ }^{14} \mathrm{C}$ analyses that secondary organic carbon stemming from fossil emissions might represent $12 \%$ of OC on the annual average. In other words, fossil fuel emissions could represent approximately a quarter $(12+11=23 \%)$ of total OA mass when both primary and secondary OA fractions are accounted for. The analysis of the components' seasonal variations shows relatively stable HOA contributions (9-14\%), higher contributions of BBOA during cold seasons due to residential heating (up to $36 \%$ of OA on average during winter) and higher OOA contributions during summer related to enhanced photochemical production ( $86 \%$ of OA on average).

$\mathrm{OA}$ can be further characterized investigating specific organic fragments. $\mathrm{m} / z 44$ (mainly $\mathrm{CO}_{2}^{+}$) and 43 (mainly $\mathrm{C}_{2} \mathrm{H}_{3} \mathrm{O}^{+}$) signals give insights on the nature of $\mathrm{OA}$, as the former is primarily related to acids or acid-derived species whereas the latter is mostly associated with non-acid oxygenates (Duplissy et al., 2011; Ng et al., 2011b). Daily variations of both $f_{44}$ and $f_{43}$ are shown in Fig. 6, along with other major organic fragments. On average, $f_{44}$ is predominant with respect to $f_{43}$ (15 and $7 \%$, respectively), which indicates that acid species dominate the OA composition with respect to non-acid oxygenates. Both fragments present different daily patterns underlying distinct mechanisms of for- mation. Acids' contributions are enhanced during daytime, which could be explained by photochemical processes and/or daily BLH variations as already discussed for sulfate. Nonacid oxygenates exhibit higher contributions during nighttime than daytime. This pattern could be due to (i) the formation of semi-volatile non-acids during night-time by e.g. condensation (Lanz et al., 2007), (ii) their degradation during daytime by e.g. fragmentation reactions (Daumit et al., 2013) and/or (iii) their conversion into acid-related species during daytime e.g. by functionalization or oligomerization reactions (Daumit et al., 2013). It should be specified that the enhancement of $f_{44}$ during daytime and the increasing of $f_{43}$ during night-time only represent a small fraction of their total contributions to OA (Fig. 6), suggesting that most acid and non-acid oxygenates have been formed before reaching our sampling site, i.e. have been imported from other regions. The other major OA fragments $(m / z 29,55,57$ and 60) present (i) constant contributions for $f_{29}$ due its various emission sources (HOA, BBOA, OOA; Ng et al., 2011c), (ii) the absence of lunch peak for $f_{55}$ (and also for the absolute contributions of $m / z 55$ ) consistent with the presumable low influence of cooking emissions, (iii) morning and evening peaks for $f_{57}$ characteristic of fossil fuel emissions and (iv) higher contributions during night-time for $f_{60}$ in agreement with its biomass burning origin.

Using $f_{43}$ and $f_{44}$, the oxygen-to-carbon $(\mathrm{O} / \mathrm{C})$, OM-to$\mathrm{OC}(\mathrm{OM} / \mathrm{OC})$ and hydrogen-to-carbon $(\mathrm{H} / \mathrm{C})$ ratios and 

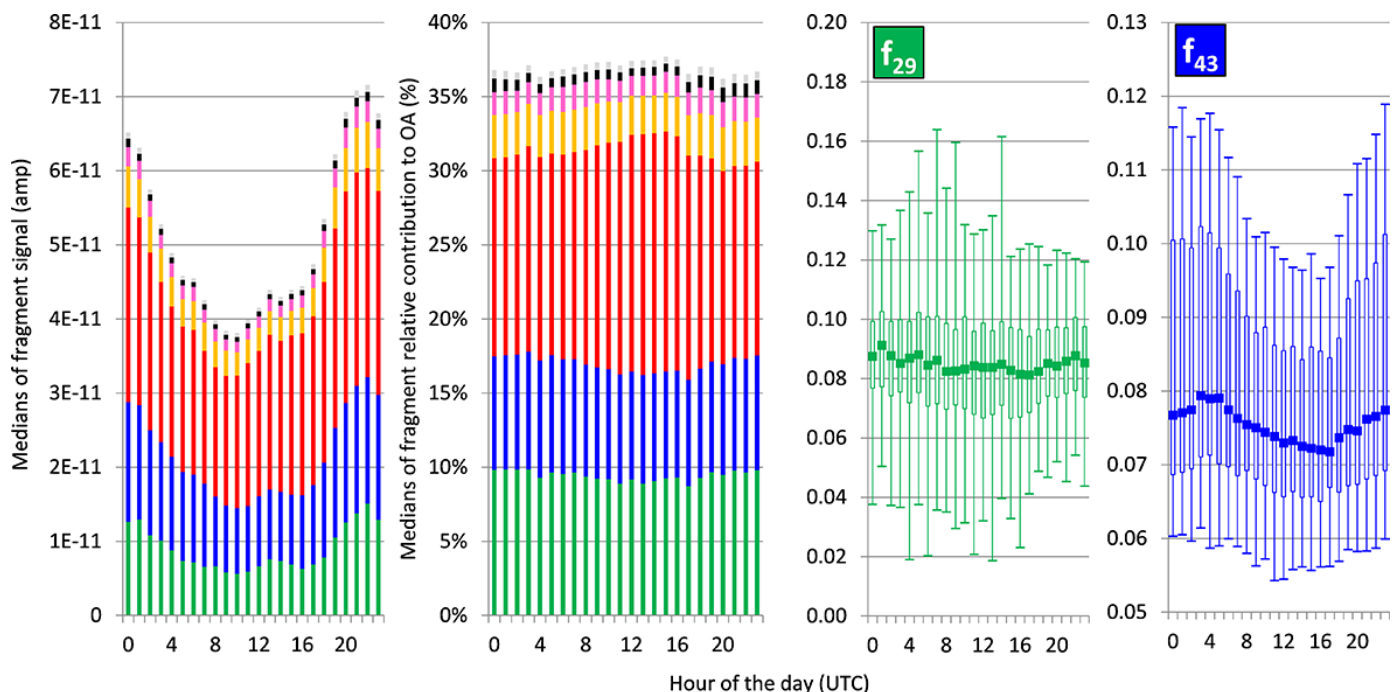

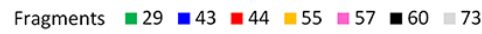

Hour of the day (UTC)
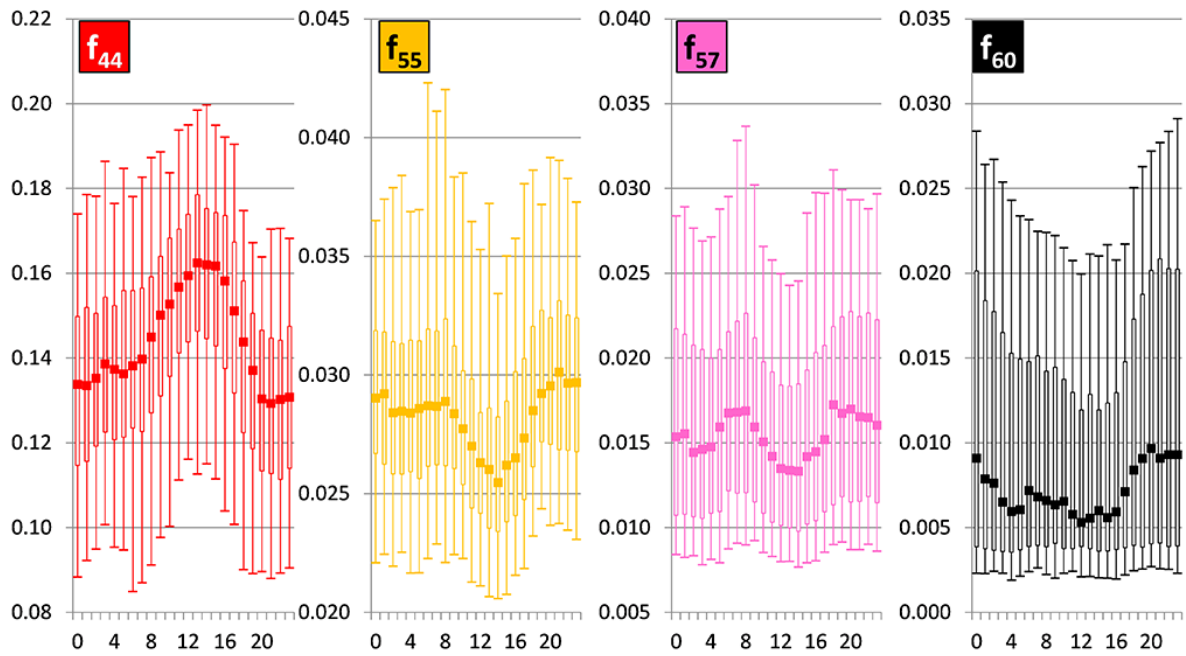

Hour of the day (UTC)

Figure 6. Annual statistics describing the daily cycles of the major organic fragments. Box plots are constructed from the 5th, 25th, 50th, 75th and 95th percentiles.

the carbon oxidation state $(\mathrm{OSc})$ have been estimated for total OA based on the methodologies described by Aiken et al. (2008), Kroll et al. (2011) and Ng et al. (2011b) and applying the parameterization defined in Canagaratna et al. (2015), which can be summarized as follows:

$$
\begin{aligned}
\mathrm{O} / \mathrm{C} & =4.31 f_{44}+0.079, \\
\mathrm{OM} / \mathrm{OC} & =1.28 \mathrm{O} / \mathrm{C}+1.17, \\
\mathrm{H} / \mathrm{C} & =1.12+6.74 f_{43}-17.77 f_{43}^{2}, \\
\mathrm{OSc} & =2 \cdot \mathrm{O} / \mathrm{C}-\mathrm{H} / \mathrm{C},
\end{aligned}
$$

with $\mathrm{H} / \mathrm{C}$ (and therefore $\mathrm{OSc}$ ) being estimated only when $f_{44}>0.05$ and $f_{43}>0.04$ (Canagaratna et al., 2015). Uncertainties associated with these estimates - in particular based on ACSM measurements - are discussed in Sect. S3 (see also
Fig. S8). Comparisons with studies using (high-resolution time-of-flight) AMS instruments will not be reported and only variations within this dataset will be discussed (see Sect. S3). Seasonal and annual O / C, OM / OC, H / C and $\mathrm{OSc}$ are shown in Fig. 7. High $\mathrm{O} / \mathrm{C}, \mathrm{OM} / \mathrm{OC}$ and $\mathrm{OSc}$ are found on the annual scale (medians of $0.7,2.1$ and -0.2, respectively), reflecting once more the aged, oxidized properties of organic matter at the study site, consistent with the predominance of the OOA component. Little seasonal variations are observed for the aforementioned variables, hence highlighting the high degree of oxidation of OA throughout the year (Fig. 7). The unexpectedly high degree of oxygenation of OA observed during cold seasons despite the increased contribution of primary BBOA (with $\mathrm{OM} / \mathrm{OC}$ ratios of 1.4-1.6) could be explained by the contribution of sec- 
ondary BBOA in our OOA factor during these cold seasons, which could be associated with the enhancement of e.g. dicarboxylic and ketocarboxylic acid contents (Kundu et al., 2010) that have extremely high OM / OC ratios (up to 3.8 and 3.1, respectively; Turpin and Lim, 2001). This assumption is supported by the higher proportion of $f_{60}$ in our OOA factor (discussed in Sects. 3.2 and S2), as well as the surprisingly high OM / OC ratio observed for OOA during winter (2.5 compared to 2.2-2.4 during the other seasons). Note that Canonaco et al. (2015) also report a higher $f_{44}$ in (LV-) OOA in winter compared to summer in Zurich (Switzerland). According to these authors, this could be due to enhanced aqueous-phase production of (LV-) OOA in clouds or hygroscopic aerosols in winter, which would lead to higher levels of oxygenation compared to gas-phase oxidation mechanisms typically occurring during summer.

\subsection{Possible implications for PM abatement strategies}

In order to investigate the characteristics of fine aerosol pollution events, the variations of NR-PM 1 chemical composition and OA factors' contributions as a function of total NR-PM $\mathrm{P}_{1}$ mass are examined. This investigation is made on the annual (Fig. 8, discussion below) and seasonal scales (Fig. S9, discussion in Sect. S4). Distinct trends are observed depending on the chemical species and OA components studied. The proportion of nitrate is clearly enhanced with increasing NR-PM ${ }_{1}$ levels (from $\sim 10$ to $>30 \%$ when [NR$\left.\mathrm{PM}_{1}\right]>30 \mu \mathrm{g} \mathrm{m}^{-3}$ ), indicating that nitrate - or $\mathrm{NO}_{x}$ - abatement policies should be highly effective when attempting to limit $\mathrm{PM}_{1}$ pollution events in the Upper Po Valley. Sulfate shows an opposite trend with decreasing relative contribution when NR-PM $\mathrm{P}_{1}$ mass increases (e.g. $<5 \%$ when [NR$\left.\mathrm{PM}_{1}\right]>50 \mu \mathrm{g} \mathrm{m}^{-3}$ ), likely due to the lower concentrations of sulfate during cold seasons, when the highest number of pollution events is observed. The proportion of organics is substantial (48-66\%) independently of NR-PM 1 mass, justifying once again the importance of determining its sources to design adequate abatement policies. When focusing on the organic fraction, BBOA is the only OA factor exhibiting increased contributions (from $\sim 10$ to $>40 \%$ ) with increased NR-PM 1 mass (from $<10$ to $>60 \mu \mathrm{g} \mathrm{m}^{-3}$ ), which points out the PM abatement potential of effective biomass burning emission reductions. HOA levels are rather constant throughout the year and therefore their proportions steadily decrease when NR-PM 1 levels increase, implying that local fossil-fuel-related emissions of primary $\mathrm{OC}$ are not the main responsible for submicron pollution events observed at the study site on the annual scale. Although OOA always represents a major fraction of OA (41-75\% depending on the mass bin studied), its contribution steadily decreases with increasing NR-PM 1 mass. This unexpected result signifies that even though aged secondary oxidized organics are the main contributor to OA on the annual average (66\%), they do not play a prominent role in fine PM acute pollution events.
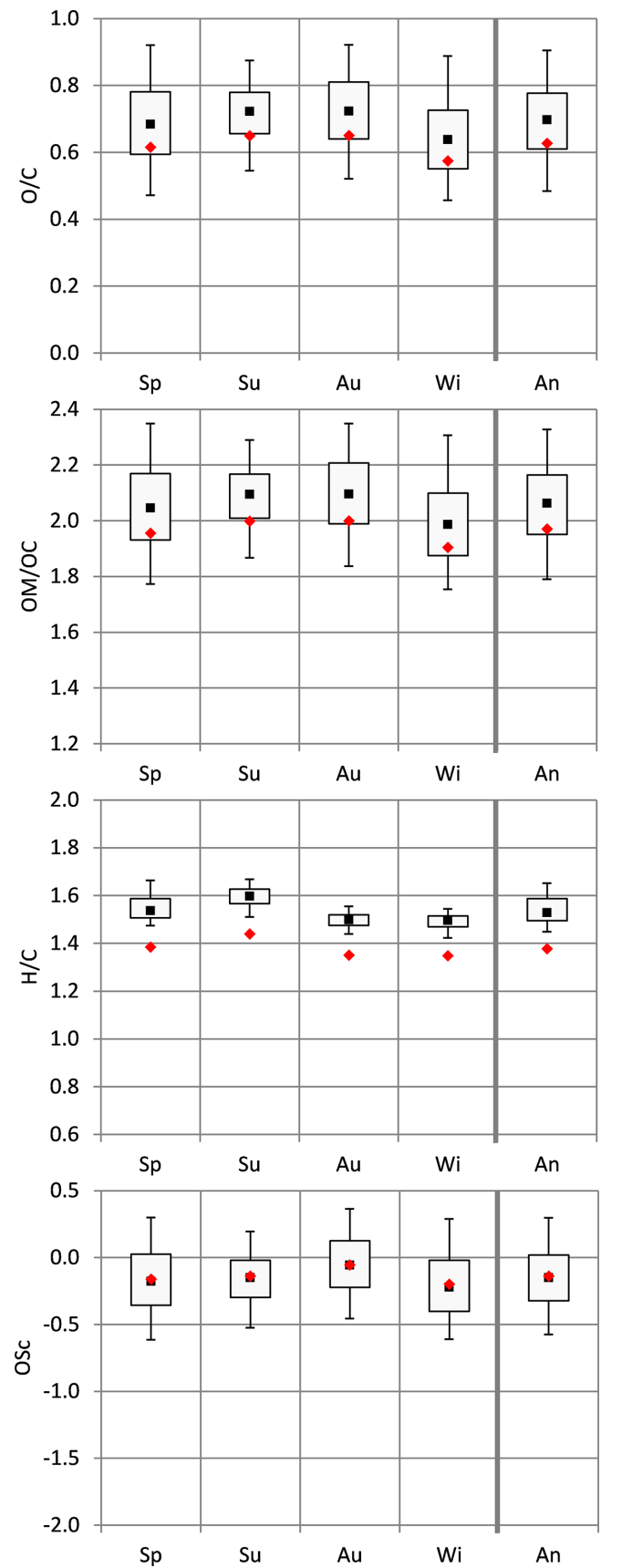

Figure 7. Seasonal and annual O / C, OM / OC, H / C and OSc of ambient OA. Sp: spring (MAM); Su: summer (JJA); Au: autumn (SON); Wi: winter (DJF); An: annual. Black: 5th, 25th, 50th, 75th and 95th percentiles estimates following Canagaratna et al. (2015); red: median estimates following Aiken et al. (2008) for O / C and $\mathrm{OM} / \mathrm{C}, \mathrm{Ng}$ et al. (2011b) for H / C, and Aiken et al. (2008), Kroll et al. (2011) and $\mathrm{Ng}$ et al. (2011b) for OSc. Note that the authors do not recommend comparing absolute $\mathrm{O} / \mathrm{C}$, OM/OC and OSc values reported here with other AMS studies, given the uncertainties associated with $f_{44}$ quantifications from ACSM measurements (please see text). 

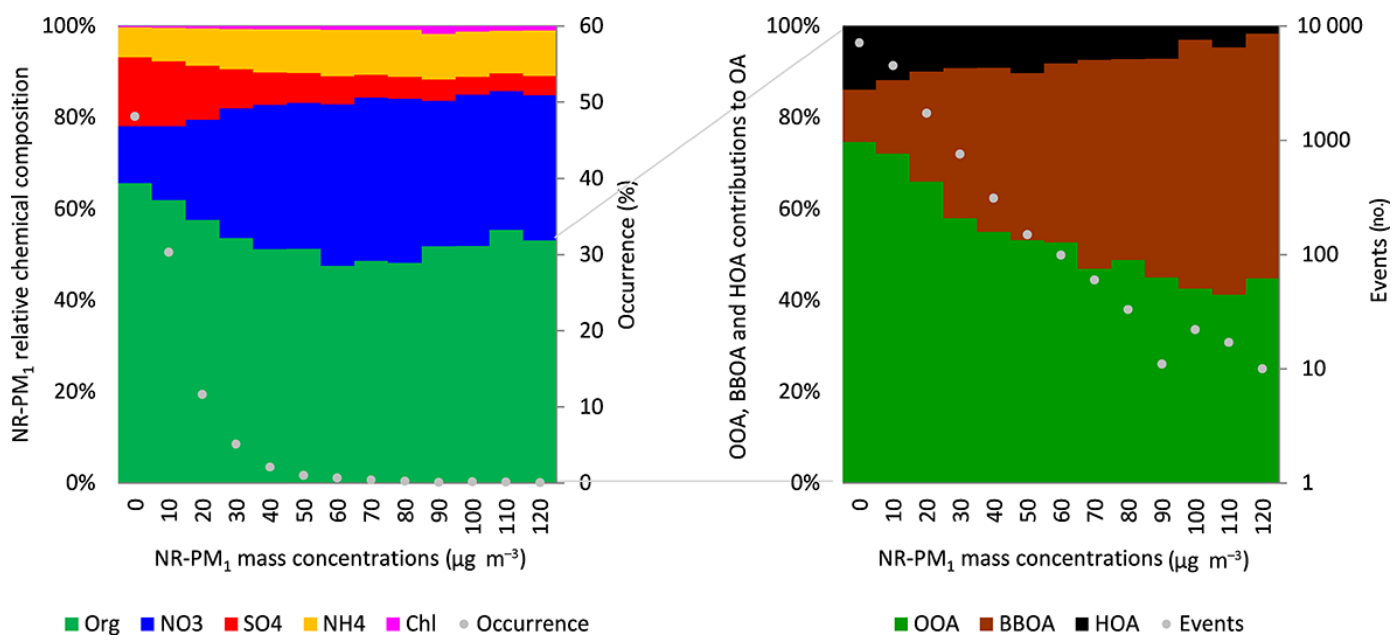

Figure 8. NR-PM 1 relative chemical composition (left) and OA factor contributions (right) averages as a function of NR-PM $\mathrm{N}_{1}$ mass concentrations (bins of $10 \mu \mathrm{g} \mathrm{m}^{-3}$ ). Occurrence (\%, left) and number of pollution events (no., right) are indicated (solid dots) for each NR-PM bin. Note that one event corresponds to one $30 \mathrm{~min}$ average.

Current European legislation sets daily and/or annual PM limit values depending on the size fraction addressed (Directive 2008/50/EC). Volume size distributions suggest that approximately $90 \%$ of the $\mathrm{PM}_{2.5}$ mass concentration is borne by particles below an aerodynamic diameter of $1 \mu \mathrm{m}$ at the study site (Putaud et al., 2014a). Therefore, measures tackling the main constituents of the submicron aerosol fraction would be efficient for complying with $\mathrm{PM}_{2.5}$ legislations. Based on the chemical characterization of NR-PM 1 and SA of its organic fraction with a time resolution of $30 \mathrm{~min}$ over 1 year, this study provides new evidence which could orient PM abatement strategies also at similar regional background sites of the Po Valley. On the annual scale, OA and especially OOA should be of main concern given their predominance in NR-PM 1 chemical composition (Fig. 3). On the seasonal scale, efforts should be directed towards the cold seasons (winter and early spring), for which the highest

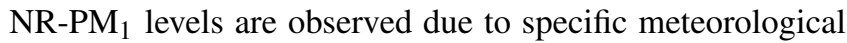
conditions (e.g. low BLH, low temperatures) and emission sources (e.g. biomass burning, Figs. 3 and 5). In particular, measures addressing emissions of $\mathrm{NO}_{x}$ and $\mathrm{BBOA}$ would be the most efficient for reducing the magnitude and frequency of PM pollution events (Fig. 8).

Recommendations for PM abatement strategies are formulated here from a legislative perspective, which aims at decreasing PM levels. Although diminishing PM levels should help reducing PM impacts, the existence of a direct causal relationship can be debatable since each chemical component has a specific effect on human health (WHO, 2013), the radiative forcing (Boucher et al., 2013) or ecosystems (e.g. Carslaw et al., 2010). For instance, implementing policies aiming at mitigating nitrate concentrations - as suggested previously in this section - would likely have limited health benefits according to toxicological studies (Reiss et al., 2007; Schlesinger and Cassee, 2003) and should lead to an increased global warming (Boucher et al., 2013). However, measures reducing BBOA levels should be beneficial, since the cardiovascular effects of biomass burning particles have been widely reported in the literature (Bølling et al., 2009; Miljevic et al., 2010; Naeher et al., 2007) and could be similar to those of traffic-emitted particles (WHO, 2013, and references therein), whereas their impacts on the radiative forcing could be null (Boucher et al., 2013). Strategies aiming at reducing solely PM mass are therefore limited, and an assessment of their impacts - e.g. using integrated assessment models (Carnevale et al., 2012; Janssen et al., 2009) with appropriate parameterizations of fundamental processes - would be beneficial.

\section{Conclusion and perspectives}

The NR-PM 1 chemical composition and the apportionment of the organic fraction have been investigated for the first time with this completeness at a regional background site of the Po Valley (Italy), using high-time-resolution (30 min) and long-term (1 year) measurements with a state-of-theart quality-assured ACSM and the most advanced factor analysis methods. Comparisons between two ACSMs show very good time series correlations for the major compounds $\left(0.91<r^{2}<0.98, n=1402\right)$ but with discrepancies in their absolute concentrations $(0.9<$ slopes $<1.4)$. These results are promising with regard to the consistency of ACSM measurements at different locations, but they also underline the importance of conducting inter-ACSM comparisons to define common protocols and assure data comparability among the European ACSM network (see Crenn et al., 2015). Comparisons between ACSM and independent analytical technique measurements show an overall good agreement for 
major components throughout the year (typically $r^{2}>0.8$ ). Discrepancies observed in time series correlations and quantifications (i.e. slopes) for specific species and seasons (e.g. nitrate in summer) are attributed to filter sampling artefacts. These results are encouraging regarding the potential implementation of ACSMs in air quality networks as a replacement of traditional filter-based techniques to measure the artefactfree chemical composition of fine aerosols with high time resolution. Additional comparison studies are nevertheless needed to support our results, and further technical development allowing the refractory carbon fraction to be accounted for is required.

NR-PM $M_{1}$ and $\mathrm{PM}_{1}$ levels measured in the upper Po Valley (14.2 and $15.3 \mathrm{\mu g} \mathrm{m}^{-3}$ of the annual average, respectively) are among the highest reported in Europe, stressing the need for implementing effective PM abatement strategies in this region. On average, the chemical composition of nonrefractory submicron aerosol is dominated by organic aerosol $(58 \%$ of NR-PM 1 ), which is composed of HOA $(11 \%$ of OA), BBOA (23\%) and OOA (66\%). Fossil fuel combustion is thus not a major source of primary OA in this area of the Po Valley. Primary BBOA significantly contributes to $\mathrm{OA}$ of the annual average and especially during winter $(36 \%)$. Our OOA component is highly oxidized and aged with an LV-OOA spectral signature, a large proportion of acid-related species and high OM / OC ratios. Highly oxidized OA properties are observed during all seasons, surprisingly including winter, which could reflect secondary BBOA influence and OOA aqueous-phase formation processes during cold seasons. Further research aiming at identifying the sources of OOA - including secondary BBOA using e.g. high-resolution mass spectrometric techniques (Crippa et al., 2013) or proton nuclear magnetic resonance (Paglione et al., 2014) - and better estimating O / C, OM / OC and OSc parameters would be beneficial.

Specific recommendations for PM abatement strategies at a regional level can be suggested. The higher frequency of particulate pollution peaks observed during cold seasons suggests an orientation of future policies towards these periods. BBOA and nitrate present increasing relative contributions with increasing fine aerosol levels, which suggests that wood burning and $\mathrm{NO}_{x}$ emission reductions should notably decrease NR-PM ${ }_{1}$ pollution events. Note that these recommendations are only formulated in the perspective of reducing PM levels, assuming a subsequent reduction of PM impacts. Additional dimensions - e.g. specific impacts of each chemical component, short- vs. long-term exposure, co-benefit of sanitary and climatic impacts - should also be considered when defining PM abatement strategies. In a broader context, the use of high-time-resolution analytical techniques for the measurement of PM pollution properties can help better shape our future air quality policies.

\section{Data availability}

Raw and processed data are archived at the European Commission - Joint Research Centre and are available on request.

\section{The Supplement related to this article is available online at doi:10.5194/acp-16-12875-2016-supplement.}

Acknowledgements. This study was partially supported by the European Union's project ACTRIS (Aerosols, Clouds, and Trace gases Research InfraStructure Network, EU FP7-262254). R. Passarella (EC-JRC), K. Douglas (EC-JRC), V. Pedroni (EC-JRC) and M. Stracquadanio (ENEA) are thanked for their help on the field and/or for the chemical analyses of filters. P. Croteau (Aerodyne) is acknowledged for his technical support on the operation of the ACSM. N. Jensen (EC-JRC) is thanked for providing gas-phase data. M. Crippa (EC-JRC) is acknowledged for her valuable advice.

Edited by: W. Maenhaut

Reviewed by: three anonymous referees

\section{References}

Aerodyne: Aerosol Chemical Speciation Monitor: Data Acquisition Software Manual, available at: ftp://ftp.aerodyne.com/ ACSM/ACSM_Manuals/ACSM_DAQ_Manual.pdf (last access: 15 February 2016), 2010a.

Aerodyne: Aerosol Chemical Speciation Monitor: Data Analysis Software Manual, available at: ftp://ftp.aerodyne.com/ ACSM/ACSM_Manuals/ACSM_Igor_Manual.pdf (last access: 15 February 2016), 2010b.

Aiken, A. C., DeCarlo, P. F., Kroll, J. H., Worsnop, D. R., Huffman, J. A., Docherty, K. S., Ulbrich, I. M., Mohr, C., Kimmel, J. R., Sueper, D., Sun, Y., Zhang, Q., Trimborn, A., Northway, M., Ziemann, P. J., Canagaratna, M. R., Onasch, T. B., Alfarra, M. R., Prevot, A. S. H., Dommen, J., Duplissy, J., Metzger, A., Baltensperger, U., and Jimenez, J. L.: O / C and OM / OC ratios of primary, secondary, and ambient organic aerosols with highresolution time-of-flight aerosol mass spectrometry, Environ. Sci. Technol., 42, 4478-4485, doi:10.1021/es703009q, 2008.

Allan, J. D., Jimenez, J. L., Williams, P. I., Alfarra, M. R., Bower, K. N., Jayne, J. T., Coe, H., and Worsnop, D. R.: Quantitative sampling using an Aerodyne aerosol mass spectrometer 1. Techniques of data interpretation and error analysis, J. Geophys. Res.Atmos., 108, 4090, doi:10.1029/2002JD002358, 2003 a.

Allan, J. D., Alfarra, M. R., Bower, K. N., Williams, P. I., Gallagher, M. W., Jimenez, J. L., McDonald, A. G., Nemitz, E., Canagaratna, M. R., Jayne, J. T., Coe, H., and Worsnop, D. R.: Quantitative sampling using an Aerodyne aerosol mass spectrometer 2. Measurements of fine particulate chemical composition in two U.K. cities, J. Geophys. Res.-Atmos., 108, 4091, doi:10.1029/2002JD002359, 2003b.

Amato, F., Pandolfi, M., Escrig, A., Querol, X., Alastuey, A., Pey, J., Perez, N., and Hopke, P. K.: Quantifying road dust 
resuspension in urban environment by Multilinear Engine: a comparison with PMF2, Atmos. Environ., 43, 2770-2780, doi:10.1016/j.atmosenv.2009.02.039, 2009.

Belis, C. A., Cancelinha, J., Duane, M., Forcina, V., Pedroni, V., Passarella, R., Tanet, G., Douglas, K., Piazzalunga, A., Bolzacchini, E., Sangiorgi, G., Perrone, M.-G., Ferrero, L., Fermo, P., and Larsen, B. R.: Sources for PM air pollution in the Po Plain, Italy: I. Critical comparison of methods for estimating biomass burning contributions to benzo(a)pyrene, Atmos. Environ., 45, 7266-7275, doi:10.1016/j.atmosenv.2011.08.061, 2011.

Belis, C. A., Karagulian, F., Larsen, B. R., and Hopke, P. K.: Critical review and meta-analysis of ambient particulate matter source apportionment using receptor models in Europe, Atmos. Environ., 69, 94-108, doi:10.1016/j.atmosenv.2012.11.009, 2013.

Bølling, A. K., Pagels, J., Yttri, K., Barregard, L., Sallsten, G., Schwarze, P. E., and Boman, C.: Health effects of residential wood smoke particles: the importance of combustion conditions and physicochemical particle properties, Part. Fibre Toxicol., 6, 29, 20 pp., doi:10.1186/1743-8977-6-29, 2009.

Boucher, O., Randall, D., Artaxo, P., Bretherton, C., Feingold, G., Forster, P., Kerminen, V.-M., Kondo, Y., Liao, H., Lohmann, U., Rasch, P., Satheesh, S. K., Sherwood, S., Stevens, B., and Zhang, X.: Clouds and aerosols, in: Climate Change 2013: The Physical Science Basis, Contribution of Working Group I to the Fifth Assessment Report of the Intergovernmental Panel on Climate Change, edited by: Stocker, T. F., Qin, D., Plattner, G.-K., Tignor, M., Allen, S. K., Boschung, J., Nauels, A., Xia, Y., Bex, V., and Midgley, P. M., Cambridge University Press, Cambridge, United Kingdom and New York, NY, USA, 2013.

Budisulistiorini, S. H., Canagaratna, M. R., Croteau, P. L., Marth, W. J., Baumann, K., Edgerton, E. S., Shaw, S. L., Knipping, E. M., Worsnop, D. R., Jayne, J. T., Gold, A., and Surratt, J. D.: Real-time continuous characterization of secondary organic aerosol derived from isoprene epoxydiols in downtown Atlanta, Georgia, using the Aerodyne aerosol chemical speciation monitor, Environ. Sci. Technol., 47, 5686-5694, doi:10.1021/es400023n, 2013.

Budisulistiorini, S. H., Canagaratna, M. R., Croteau, P. L., Baumann, K., Edgerton, E. S., Kollman, M. S., Ng, N. L., Verma, V., Shaw, S. L., Knipping, E. M., Worsnop, D. R., Jayne, J. T., Weber, R. J., and Surratt, J. D.: Intercomparison of an Aerosol Chemical Speciation Monitor (ACSM) with ambient fine aerosol measurements in downtown Atlanta, Georgia, Atmos. Meas. Tech., 7, 1929-1941, doi:10.5194/amt-7-1929-2014, 2014.

Canagaratna, M. R., Jayne, J. T., Jimenez, J. L., Allan, J. D., Alfarra, M. R., Zhang, Q., Onasch, T. B., Drewnick, F., Coe, H., Middlebrook, A., Delia, A., Williams, L. R., Trimborn, A. M., Northway, M. J., DeCarlo, P. F., Kolb, C. E., Davidovits, P., and Worsnop, D. R.: Chemical and microphysical characterization of ambient aerosols with the Aerodyne aerosol mass spectrometer, Mass Spectrom. Rev., 26, 185-222, doi:10.1002/mas.20115, 2007.

Canagaratna, M. R., Jimenez, J. L., Kroll, J. H., Chen, Q., Kessler, S. H., Massoli, P., Hildebrandt Ruiz, L., Fortner, E., Williams, L. R., Wilson, K. R., Surratt, J. D., Donahue, N. M., Jayne, J. T., and Worsnop, D. R.: Elemental ratio measurements of o rganic compounds using aerosol mass spectrometry: characterization, improved calibration, and implications, Atmos. Chem. Phys., 15, 253-272, doi:10.5194/acp-15-253-2015, 2015.
Canonaco, F., Crippa, M., Slowik, J. G., Baltensperger, U., and Prévôt, A. S. H.: SoFi, an IGOR-based interface for the efficient use of the generalized multilinear engine (ME-2) for the source apportionment: ME-2 application to aerosol mass spectrometer data, Atmos. Meas. Tech., 6, 3649-3661, doi:10.5194/amt6-3649-2013, 2013.

Canonaco, F., Slowik, J. G., Baltensperger, U., and Prévôt, A. S. H.: Seasonal differences in oxygenated organic aerosol composition: implications for emissions sources and factor analysis, Atmos. Chem. Phys., 15, 6993-7002, doi:10.5194/acp-15-69932015, 2015.

Carbone, C., Decesari, S., Paglione, M., Giulianelli, L., Rinaldi, M., Marinoni, A., Cristofanelli, P., Didiodato, A., Bonasoni, P., Fuzzi, S., and Facchini, M. C.: 3-year chemical composition of free tropospheric $\mathrm{PM}_{1}$ at the Mt. Cimone GAW global station - South Europe - 2165 m a.s.l., Atmos. Environ., 87, 218-227, doi:10.1016/j.atmosenv.2014.01.048, 2014.

Carnevale, C., Finzi, G., Pisoni, E., Volta, M., Guariso, G., Gianfreda, R., Maffeis, G., Thunis, P., White, L., and Triacchini, G.: An integrated assessment tool to define effective air quality policies at regional scale, Environ. Modell. Softw., 38, 306-315, doi:10.1016/j.envsoft.2012.07.004, 2012.

Carslaw, K. S., Boucher, O., Spracklen, D. V., Mann, G. W., Rae, J. G. L., Woodward, S., and Kulmala, M.: A review of natural aerosol interactions and feedbacks within the Earth system, Atmos. Chem. Phys., 10, 1701-1737, doi:10.5194/acp-10-17012010, 2010.

Cavalli, F., Viana, M., Yttri, K. E., Genberg, J., and Putaud, J.-P.: Toward a standardised thermal-optical protocol for measuring atmospheric organic and elemental carbon: the EUSAAR protocol, Atmos. Meas. Tech., 3, 79-89, doi:10.5194/amt-3-79-2010, 2010.

Chow, J. C., Watson, J. G., Lowenthal, D. H., and Magliano, K. L.: Loss of $\mathrm{PM}_{2.5}$ nitrate from filter samples in central California, J. Air Waste Manage. Assoc., 55, 1158-1168, doi:10.1080/10473289.2005.10464704, 2005.

Clegg, S. L., Brimblecombe, P., and Wexler, A. S.: Thermodynamic model of the system $\mathrm{H}^{+}-\mathrm{NH}_{4}^{+}-\mathrm{SO}_{4}^{2-}-\mathrm{NO}_{3}^{-}-\mathrm{H}_{2} \mathrm{O}$ at tropospheric temperatures, J. Phys. Chem. A, 102, 2137-2154, doi:10.1021/jp973042r, 1998.

Clerici, M. and Mélin, F.: Aerosol direct radiative effect in the Po Valley region derived from AERONET measurements, Atmos. Chem. Phys., 8, 4925-4946, doi:10.5194/acp-8-4925-2008, 2008.

Crawford, J., Cohen, D., Dyer, L., and Zahorowski, W.: Receptor modelling with PMF2 and ME2 using aerosol data from Hong Kong, Australian Nuclear Science and Technology Organisation (ANSTO), available at: http://apo.ansto.gov.au/ dspace/bitstream/10238/201/1/ANSTO-E-756.pdf (last access: 15 February 2016), 2005.

Crenn, V., Sciare, J., Croteau, P. L., Verlhac, S., Fröhlich, R., Belis, C. A., Aas, W., Äijälä, M., Alastuey, A., Artiñano, B., Baisnée, D., Bonnaire, N., Bressi, M., Canagaratna, M., Canonaco, F., Carbone, C., Cavalli, F., Coz, E., Cubison, M. J., Esser-Gietl, J. K., Green, D. C., Gros, V., Heikkinen, L., Herrmann, H., Lunder, C., Minguillón, M. C., Mocnik, G., O’Dowd, C. D., Ovadnevaite, J., Petit, J.-E., Petralia, E., Poulain, L., Priestman, M., Riffault, V., Ripoll, A., Sarda-Estève, R., Slowik, J. G., Setyan, A., Wiedensohler, A., Baltensperger, U., Prévôt, A. S. H., Jayne, 
J. T., and Favez, O.: ACTRIS ACSM intercomparison - Part 1: Reproducibility of concentration and fragment results from 13 individual Quadrupole Aerosol Chemical Speciation Monitors (Q-ACSM) and consistency with co-located instruments, Atmos. Meas. Tech., 8, 5063-5087, doi:10.5194/amt-8-5063-2015, 2015.

Crippa, M., DeCarlo, P. F., Slowik, J. G., Mohr, C., Heringa, M. F., Chirico, R., Poulain, L., Freutel, F., Sciare, J., Cozic, J., Di Marco, C. F., Elsasser, M., Nicolas, J. B., Marchand, N., Abidi, E., Wiedensohler, A., Drewnick, F., Schneider, J., Borrmann, S., Nemitz, E., Zimmermann, R., Jaffrezo, J.-L., Prévôt, A. S. H., and Baltensperger, U.: Wintertime aerosol chemical composition and source apportionment of the organic fraction in the metropolitan area of Paris, Atmos. Chem. Phys., 13, 961-981, doi:10.5194/acp-13-961-2013, 2013.

Crippa, M., Canonaco, F., Lanz, V. A., Äijälä, M., Allan, J. D., Carbone, S., Capes, G., Ceburnis, D., Dall'Osto, M., Day, D. A., DeCarlo, P. F., Ehn, M., Eriksson, A., Freney, E., Hildebrandt Ruiz, L., Hillamo, R., Jimenez, J. L., Junninen, H., Kiendler-Scharr, A., Kortelainen, A.-M., Kulmala, M., Laaksonen, A., Mensah, A. A., Mohr, C., Nemitz, E., O’Dowd, C., Ovadnevaite, J., Pandis, S. N., Petäjä, T., Poulain, L., Saarikoski, S., Sellegri, K., Swietlicki, E., Tiitta, P., Worsnop, D. R., Baltensperger, U., and Prévôt, A. S. H.: Organic aerosol components derived from 25 AMS data sets across Europe using a consistent ME-2 based source apportionment approach, Atmos. Chem. Phys., 14, 61596176, doi:10.5194/acp-14-6159-2014, 2014.

Cubison, M. J., Ortega, A. M., Hayes, P. L., Farmer, D. K., Day, D., Lechner, M. J., Brune, W. H., Apel, E., Diskin, G. S., Fisher, J. A., Fuelberg, H. E., Hecobian, A., Knapp, D. J., Mikoviny, T., Riemer, D., Sachse, G. W., Sessions, W., Weber, R. J., Weinheimer, A. J., Wisthaler, A., and Jimenez, J. L.: Effects of aging on organic aerosol from open biomass burning smoke in aircraft and laboratory studies, Atmos. Chem. Phys., 11, 12049-12064, doi:10.5194/acp-11-12049-2011, 2011.

Dall'Osto, M., Paglione, M., Decesari, S., Facchini, M. C., O'Dowd, C., Plass-Duellmer, C., and Harrison, R. M.: On the Origin of AMS "Cooking Organic Aerosol" at a Rural Site, Environ. Sci. Technol., 49, 13964-13972, doi:10.1021/acs.est.5b02922, 2015.

Daumit, K. E., Kessler, S. H., and Kroll, J. H.: Average chemical properties and potential formation pathways of highly oxidized organic aerosol, Faraday Discuss., 165, 181-202, doi:10.1039/c3fd00045a, 2013.

Decesari, S., Allan, J., Plass-Duelmer, C., Williams, B. J., Paglione, M., Facchini, M. C., O'Dowd, C., Harrison, R. M., Gietl, J. K., Coe, H., Giulianelli, L., Gobbi, G. P., Lanconelli, C., Carbone, C., Worsnop, D., Lambe, A. T., Ahern, A. T., Moretti, F., Tagliavini, E., Elste, T., Gilge, S., Zhang, Y., and Dall'Osto, M.: Measurements of the aerosol chemical composition and mixing state in the Po Valley using multiple spectroscopic techniques, Atmos. Chem. Phys., 14, 12109-12132, doi:10.5194/acp-1412109-2014, 2014.

Duplissy, J., DeCarlo, P. F., Dommen, J., Alfarra, M. R., Metzger, A., Barmpadimos, I., Prevot, A. S. H., Weingartner, E., Tritscher, T., Gysel, M., Aiken, A. C., Jimenez, J. L., Canagaratna, M. R., Worsnop, D. R., Collins, D. R., Tomlinson, J., and Baltensperger, U.: Relating hygroscopicity and composition of or- ganic aerosol particulate matter, Atmos. Chem. Phys., 11, 11551165, doi:10.5194/acp-11-1155-2011, 2011.

EC: Commission of the European communities, Commission staff working paper, Annex to the communication on thematic strategy on air pollution and the directive on "Ambient air quality and cleaner air for Europe", Impact assessment, SEC (2005) 1133, available at: http://ec.europa.eu/environment/archives/cafe/pdf/ ia_report_en050921_final.pdf (last access: 15 February 2016), 2005.

EEA: Air quality in Europe - 2013 report, European Environment Agency (EEA), report no 9/2013, publication, available at: http: //www.eea.europa.eu/publications/air-quality-in-europe-2013 (last access: 15 February 2016), 2013.

Ervens, B., Turpin, B. J., and Weber, R. J.: Secondary organic aerosol formation in cloud droplets and aqueous particles (aqSOA): a review of laboratory, field and model studies, Atmos. Chem. Phys., 11, 11069-11102, doi:10.5194/acp-1111069-2011, 2011.

EU: Directive 2008/50/EC of the European Parliament and of the Council of 21 May 2008 on ambient air quality and cleaner air for Europe, available at: http://eur-lex.europa.eu/legal-content/ en/ALL/?uri=CELEX:32008L0050 (last access 18 July 2016), 2008.

Ferrero, L., Castelli, M., Ferrini, B. S., Moscatelli, M., Perrone, M. G., Sangiorgi, G., D’Angelo, L., Rovelli, G., Moroni, B., Scardazza, F., Mocnik, G., Bolzacchini, E., Petitta, M., and Cappelletti, D.: Impact of black carbon aerosol over Italian basin valleys: high-resolution measurements along vertical profiles, radiative forcing and heating rate, Atmos. Chem. Phys., 14, 96419664, doi:10.5194/acp-14-9641-2014, 2014.

Fröhlich, R., Crenn, V., Setyan, A., Belis, C. A., Canonaco, F., Favez, O., Riffault, V., Slowik, J. G., Aas, W., Aijälä, M., Alastuey, A., Artiñano, B., Bonnaire, N., Bozzetti, C., Bressi, M., Carbone, C., Coz, E., Croteau, P. L., Cubison, M. J., Esser-Gietl, J. K., Green, D. C., Gros, V., Heikkinen, L., Herrmann, H., Jayne, J. T., Lunder, C. R., Minguillón, M. C., Mocnik, G., O’Dowd, C. D., Ovadnevaite, J., Petralia, E., Poulain, L., Priestman, M., Ripoll, A., Sarda-Estève, R., Wiedensohler, A., Baltensperger, U., Sciare, J., and Prévôt, A. S. H.: ACTRIS ACSM intercomparison - Part 2: Intercomparison of ME-2 organic source apportionment results from 15 individual, co-located aerosol mass spectrometers, Atmos. Meas. Tech., 8, 2555-2576, doi:10.5194/amt8-2555-2015, 2015.

Gaeggeler, K., Prevot, A. S. H., Dommen, J., Legreid, G., Reimann, S., and Baltensperger, U.: Residential wood burning in an Alpine valley as a source for oxygenated volatile organic compounds, hydrocarbons and organic acids, Atmos. Environ., 42, 82788287, doi:10.1016/j.atmosenv.2008.07.038, 2008.

Gentner, D. R., Isaacman, G., Worton, D. R., Chan, A. W. H., Dallmann, T. R., Davis, L., Liu, S., Day, D. A., Russell, L. M., Wilson, K. R., Weber, R., Guha, A., Harley, R. A., and Goldstein, A. H.: Elucidating secondary organic aerosol from diesel and gasoline vehicles through detailed characterization of organic carbon emissions, P. Natl. Acad. Sci. USA, 109, 18318-18323, doi:10.1073/pnas.1212272109, 2012.

Gilardoni, S., Vignati, E., Cavalli, F., Putaud, J. P., Larsen, B. R., Karl, M., Stenström, K., Genberg, J., Henne, S., and Dentener, F.: Better constraints on sources of carbonaceous aerosols using a combined ${ }^{14} \mathrm{C}$ - macro tracer analysis in a European 
rural background site, Atmos. Chem. Phys., 11, 5685-5700, doi:10.5194/acp-11-5685-2011, 2011.

Gilardoni, S., Massoli, P., Giulianelli, L., Rinaldi, M., Paglione, M., Pollini, F., Lanconelli, C., Poluzzi, V., Carbone, S., Hillamo, R., Russell, L. M., Facchini, M. C., and Fuzzi, S.: Fog scavenging of organic and inorganic aerosol in the Po Valley, Atmos. Chem. Phys., 14, 6967-6981, doi:10.5194/acp-14-6967-2014, 2014.

Hand, J. L. and Kreidenweis, S. M.: A new method for retrieving particle refractive index and effective density from aerosol size distribution data, Aerosol Sci. Technol., 36, 1012-1026, doi:10.1080/02786820290092276, 2002.

Herich, H., Gianini, M. F. D., Piot, C., Močnik, G., Jaffrezo, J.-L., Besombes, J.-L., Prévôt, A. S. H., and Hueglin, C.: Overview of the impact of wood burning emissions on carbonaceous aerosols and PM in large parts of the Alpine region, Atmos. Environ., 89, 64-75, doi:10.1016/j.atmosenv.2014.02.008, 2014.

Heringa, M. F., DeCarlo, P. F., Chirico, R., Tritscher, T., Dommen, J., Weingartner, E., Richter, R., Wehrle, G., Prévôt, A. S. H., and Baltensperger, U.: Investigations of primary and secondary particulate matter of different wood combustion appliances with a high-resolution time-of-flight aerosol mass spectrometer, Atmos. Chem. Phys., 11, 5945-5957, doi:10.5194/acp-11-59452011, 2011.

Hu, M., Peng, J., Sun, K., Yue, D., Guo, S., Wiedensohler, A., and $\mathrm{Wu}, \mathrm{Z}$.: Estimation of size-resolved ambient particle density based on the measurement of aerosol number, mass, and chemical size distributions in the winter in Beijing, Environ. Sci. Technol., 9941-9947, doi:10.1021/es204073t, 2012.

Huang, X.-F., He, L.-Y., Hu, M., Canagaratna, M. R., Sun, Y., Zhang, Q., Zhu, T., Xue, L., Zeng, L.-W., Liu, X.-G., Zhang, Y.-H., Jayne, J. T., Ng, N. L., and Worsnop, D. R.: Highly time-resolved chemical characterization of atmospheric submicron particles during 2008 Beijing Olympic Games using an Aerodyne High-Resolution Aerosol Mass Spectrometer, Atmos. Chem. Phys., 10, 8933-8945, doi:10.5194/acp-10-8933-2010, 2010.

Janssen, S., Ewert, F., Li, H., Athanasiadis, I. N., Wien, J. J. F., Thérond, O., Knapen, M. J. R., Bezlepkina, I., AlkanOlsson, J., Rizzoli, A. E., Belhouchette, H., Svensson, M., and van Ittersum, M. K.: Defining assessment projects and scenarios for policy support: use of ontology in integrated assessment and modelling, Environ. Modell. Softw., 24, 1491-1500, doi:10.1016/j.envsoft.2009.04.009, 2009.

Jayne, J. T., Leard, D. C., Zhang, X., Davidovits, P., Smith, K. A., Kolb, C. E., and Worsnop, D. R.: Development of an aerosol mass spectrometer for size and composition analysis of submicron particles, Aerosol Sci. Technol., 33, 49-70, 2000.

Jimenez, J. L., Canagaratna, M. R., Donahue, N. M., Prevot, A. S. H., Zhang, Q., Kroll, J. H., DeCarlo, P. F., Allan, J. D., Coe, H., Ng, N. L., Aiken, A. C., Docherty, K. S., Ulbrich, I. M., Grieshop, A. P., Robinson, A. L., Duplissy, J., Smith, J. D., Wilson, K. R., Lanz, V. A., Hueglin, C., Sun, Y. L., Tian, J., Laaksonen, A., Raatikainen, T., Rautiainen, J., Vaattovaara, P., Ehn, M., Kulmala, M., Tomlinson, J. M., Collins, D. R., Cubison, M. J., Dunlea, J., Huffman, J. A., Onasch, T. B., Alfarra, M. R., Williams, P. I., Bower, K., Kondo, Y., Schneider, J., Drewnick, F., Borrmann, S., Weimer, S., Demerjian, K., Salcedo, D., Cottrell, L., Griffin, R., Takami, A., Miyoshi, T., Hatakeyama, S., Shimono, A., Sun, J. Y., Zhang, Y. M., Dzepina,
K., Kimmel, J. R., Sueper, D., Jayne, J. T., Herndon, S. C., Trimborn, A. M., Williams, L. R., Wood, E. C., Middlebrook, A. M., Kolb, C. E., Baltensperger, U., and Worsnop, D. R.: Evolution of organic aerosols in the atmosphere, Science, 326, 1525-1529, doi:10.1126/science.1180353, 2009.

Kroll, J. H., Donahue, N. M., Jimenez, J. L., Kessler, S. H., Canagaratna, M. R., Wilson, K. R., Altieri, K. E., Mazzoleni, L. R., Wozniak, A. S., Bluhm, H., Mysak, E. R., Smith, J. D., Kolb, C. E., and Worsnop, D. R.: Carbon oxidation state as a metric for describing the chemistry of atmospheric organic aerosol, Nat. Chem., 3, 133-139, doi:10.1038/nchem.948, 2011.

Kukkonen, J., Pohjola, M., Ssokhi, R., Luhana, L., Kitwiroon, N., Fragkou, L., Rantamaki, M., Berge, E., Odegaard, V., and Havardslordal, L.: Analysis and evaluation of selected localscale PM air pollution episodes in four European cities: Helsinki, London, Milan and Oslo, Atmos. Environ., 39, 2759-2773, doi:10.1016/j.atmosenv.2004.09.090, 2005.

Kundu, S., Kawamura, K., Andreae, T. W., Hoffer, A., and Andreae, M. O.: Molecular distributions of dicarboxylic acids, ketocarboxylic acids and a-dicarbonyls in biomass burning aerosols: implications for photochemical production and degradation in smoke layers, Atmos. Chem. Phys., 10, 2209-2225, doi:10.5194/acp-10-2209-2010, 2010.

Lanz, V. A., Alfarra, M. R., Baltensperger, U., Buchmann, B., Hueglin, C., and Prévôt, A. S. H.: Source apportionment of submicron organic aerosols at an urban site by factor analytical modelling of aerosol mass spectra, Atmos. Chem. Phys., 7, 15031522, doi:10.5194/acp-7-1503-2007, 2007.

Lanz, V. A., Prévôt, A. S. H., Alfarra, M. R., Weimer, S., Mohr, C., DeCarlo, P. F., Gianini, M. F. D., Hueglin, C., Schneider, J., Favez, O., D’ Anna, B., George, C., and Baltensperger, U.: Characterization of aerosol chemical composition with aerosol mass spectrometry in Central Europe: an overview, Atmos. Chem. Phys., 10, 10453-10471, doi:10.5194/acp-10-10453-2010, 2010.

Larsen, B. R., Gilardoni, S., Stenström, K., Niedzialek, J., Jimenez, J., and Belis, C. A.: Sources for PM air pollution in the Po Plain, Italy: II. Probabilistic uncertainty characterization and sensitivity analysis of secondary and primary sources, Atmos. Environ., 50, 203-213, doi:10.1016/j.atmosenv.2011.12.038, 2012.

Larssen, S., Sluyter, R., and Helmis, C.: Criteria for EUROAIRNET, the EEA Air Quality Monitoring and Information Network, available at: http://www.eea.europa.eu/publications/TEC12/at_ download/file (last access: 10 February 2016), 1999.

Lee, T., Sullivan, A. P., Mack, L., Jimenez, J. L., Kreidenweis, S. M., Onasch, T. B., Worsnop, D. R., Malm, W., Wold, C. E., Hao, W. M., and Collett, J. L.: Chemical smoke marker emissions during flaming and smoldering phases of laboratory open burning of wildland fuels, Aerosol Sci. Technol., 44, i-v, doi:10.1080/02786826.2010.499884, 2010.

Liu, P. S. K., Deng, R., Smith, K. A., Williams, L. R., Jayne, J. T., Canagaratna, M. R., Moore, K., Onasch, T. B., Worsnop, D. R., and Deshler, T.: Transmission efficiency of an aerodynamic focusing lens system: comparison of model calculations and laboratory measurements for the Aerodyne aerosol mass spectrometer, Aerosol Sci. Technol., 41, 721-733, doi:10.1080/02786820701422278, 2007.

Maimone, F., Turpin, B. J., Solomon, P., Meng, Q., Robinson, A. L., Subramanian, R., and Polidori, A.: Correction methods for organic carbon artifacts when using quartz-fiber filters in large 
particulate matter monitoring networks: the regression method and other options, J. Air Waste Manage. Assoc., 61, 696-710, doi:10.3155/1047-3289.61.6.696, 2011.

McMurry, P. H., Wang, X., Park, K., and Ehara, K.: The relationship between mass and mobility for atmospheric particles: a new technique for measuring particle density, Aerosol Sci. Technol., 36, 227-238, doi:10.1080/027868202753504083, 2002.

Middlebrook, A. M., Bahreini, R., Jimenez, J. L., and Canagaratna, M. R.: Evaluation of composition-dependent collection efficiencies for the Aerodyne aerosol mass spectrometer using field data, Aerosol Sci. Technol., 46, 258-271, doi:10.1080/02786826.2011.620041, 2012.

Miljevic, B., Heringa, M. F., Keller, A., Meyer, N. K., Good, J., Lauber, A., Decarlo, P. F., Fairfull-Smith, K. E., Nussbaumer, T., Burtscher, H., Prévôt, A. S. H., Baltensperger, U., Bottle, S. E., and Ristovski, Z. D.: Oxidative potential of logwood and pellet burning particles assessed by a novel profluorescent nitroxide probe, Environ. Sci. Technol., 44, 6601-6607, 2010.

Minguillón, M. C., Ripoll, A., Pérez, N., Prévôt, A. S. H., Canonaco, F., Querol, X., and Alastuey, A.: Chemical characterization of submicron regional background aerosols in the western Mediterranean using an Aerosol Chemical Speciation Monitor, Atmos. Chem. Phys., 15, 6379-6391, doi:10.5194/acp-15-63792015, 2015.

Naeher, L. P., Brauer, M., Lipsett, M., Zelikoff, J. T., Simpson, C. D., Koenig, J. Q., and Smith, K. R.: Woodsmoke health effects: a review, Inhal. Toxicol., 19, 67-106, doi:10.1080/08958370600985875, 2007.

Ng, N. L., Herndon, S. C., Trimborn, A., Canagaratna, M. R., Croteau, P. L., Onasch, T. B., Sueper, D., Worsnop, D. R., Zhang, Q., Sun, Y. L., and Jayne, J. T.: An aerosol chemical speciation monitor (ACSM) for routine monitoring of the composition and mass concentrations of ambient aerosol, Aerosol Sci. Technol., 45, 780-794, doi:10.1080/02786826.2011.560211, 2011a.

Ng, N. L., Canagaratna, M. R., Jimenez, J. L., Chhabra, P. S., Seinfeld, J. H., and Worsnop, D. R.: Changes in organic aerosol composition with aging inferred from aerosol mass spectra, Atmos. Chem. Phys., 11, 6465-6474, doi:10.5194/acp-11-64652011, 2011 b.

Ng, N. L., Canagaratna, M. R., Jimenez, J. L., Zhang, Q., Ulbrich, I. M., and Worsnop, D. R.: Real-time methods for estimating organic component mass concentrations from aerosol mass spectrometer data, Environ. Sci. Technol., 45, 910-916, doi:10.1021/es102951k, 2011c.

Paatero, P.: User's guide for the multilinear engine program "ME2" for fitting multilinear and quasimultilinear models, University of Helsinki, Finland, 2000.

Paatero, P. and Tapper, U.: Positive matrix factorization a nonnegative factor model with optimal utilization of error-estimates of data values, Environmetrics, 5, 111-126, doi:10.1002/env.3170050203, 1994.

Paglione, M., Saarikoski, S., Carbone, S., Hillamo, R., Facchini, M. C., Finessi, E., Giulianelli, L., Carbone, C., Fuzzi, S., Moretti, F., Tagliavini, E., Swietlicki, E., Eriksson Stenström, K., Prévôt, A. S. H., Massoli, P., Canaragatna, M., Worsnop, D., and Decesari, S.: Primary and secondary biomass burning aerosols determined by proton nuclear magnetic resonance (1H-NMR) spectroscopy during the 2008 EUCAARI campaign in the Po Valley (Italy),
Atmos. Chem. Phys., 14, 5089-5110, doi:10.5194/acp-14-50892014, 2014.

Pernigotti, D., Georgieva, E., Thunis, P., and Bessagnet, B.: Impact of meteorology on air quality modeling over the Po valley in northern Italy, Atmos. Environ., 51, 303-310, doi:10.1016/j.atmosenv.2011.12.059, 2012.

Perrone, M. G., Larsen, B. R., Ferrero, L., Sangiorgi, G., De Gennaro, G., Udisti, R., Zangrando, R., Gambaro, A., and Bolzacchini, E.: Sources of high $\mathrm{PM}_{2.5}$ concentrations in Milan, northern Italy: molecular marker data and CMB modelling, Sci. Total Environ., 414, 343-355, doi:10.1016/j.scitotenv.2011.11.026, 2012.

Petit, J.-E., Favez, O., Sciare, J., Crenn, V., Sarda-Estève, R., Bonnaire, N., Mocnik, G., Dupont, J.-C., Haeffelin, M., and LeozGarziandia, E.: Two years of near real-time chemical composition of submicron aerosols in the region of Paris using an Aerosol Chemical Speciation Monitor (ACSM) and a multiwavelength Aethalometer, Atmos. Chem. Phys., 15, 2985-3005, doi:10.5194/acp-15-2985-2015, 2015.

Pitz, M., Cyrys, J., Karg, E., Wiedensohler, A., Wichmann, H.E., and Heinrich, J.: Variability of apparent particle density of an urban aerosol, Environ. Sci. Technol., 37, 4336-4342, doi:10.1021/es034322p, 2003.

Pitz, M., Schmid, O., Heinrich, J., Birmili, W., Maguhn, J., Zimmermann, R., Wichmann, H.-E., Peters, A., and Cyrys, J.: Seasonal and diurnal variation of $\mathrm{PM}_{2.5}$ apparent particle density in urban air in Augsburg, Germany, Environ. Sci. Technol., 42, 5087-5093, 2008.

Putaud, J. P., Van Dingenen, R., and Raes, F.: Submicron aerosol mass balance at urban and semirural sites in the Milan area (Italy), J. Geophys. Res.-Atmos., 107(D22), LOP 11-1-LOP 1110, doi:10.1029/2000JD000111, 2002.

Putaud, J.-P., Van Dingenen, R., Alastuey, A., Bauer, H., Birmili, W., Cyrys, J., Flentje, H., Fuzzi, S., Gehrig, R., Hansson, H. C., Harrison, R. M., Herrmann, H., Hitzenberger, R., Huglin, C., Jones, A. M., Kasper-Giebl, A., Kiss, G., Kousa, A., Kuhlbusch, T. A. J., Loschau, G., Maenhaut, W., Molnar, A., Moreno, T., Pekkanen, J., Perrino, C., Pitz, M., Puxbaum, H., Querol, X., Rodriguez, S., Salma, I., Schwarz, J., Smolik, J., Schneider, J., Spindler, G., ten Brink, H., Tursic, J., Viana, M., Wiedensohler, A., and Raes, F.: A European aerosol phenomenology - 3: physical and chemical characteristics of particulate matter from 60 rural, urban, and kerbside sites across Europe, Atmos. Environ., 44, 1308-1320, 2010.

Putaud, J.-P., Adam, M., Belis, C. A., Bergamaschi, P., Cancellinha, J., Cavalli, F., Cescatti, A., Daou, D., Dell'Acqua, A., Douglas, K., Duerr, M., Goded, I., Grassi, F., Gruening, C., Hjorth, J., Jensen, N. R., Lagler, F., Manca, G., Martins Dos Santos, S., Passarella, R., Pedroni, V., Rocha e Abreu, P., Roux, D., Scheeren, B., and Schembari, C.: JRC-Ispra AtmosphereBiosphere-Climate Integrated monitoring Station (ABC-IS): 2011 report, JRC Technical Reports, Joint Research Centre, Ispra (Italy), available at: http://publications.jrc.ec.europa.eu/ repository/bitstream/111111111/28242/1/lb-na-25753-en-n.pdf (last access: 28 March 2014), 2013.

Putaud, J.-P., Bergamaschi, P., Bressi, M., Cavalli, F., Cescatti, A., Daou, D., Dell'acqua, A., Douglas, K., Duerr, M., Fumagalli, I., Goded Ballarin, I., Grassi, F., Gruening, C., Hjorth, J., Jensen, N., Lagler, F., Manca, G., Martins Dos Santos, S., 
Matteucci, M., Passarella, R., Pedroni, V., Pokorska, O., and Roux, D.: JRC - Ispra Atmosphere - Biosphere - Climate Integrated monitoring Station 2013 report, EUR - Scientific and Technical Research Reports, Publications Office of the European Union, available at: http://publications.jrc.ec.europa.eu/ repository/handle/111111111/33904 (last access: 19 February 2015), 2014a.

Putaud, J. P., Cavalli, F., Martins dos Santos, S., and Dell'Acqua, A.: Long-term trends in aerosol optical characteristics in the Po Valley, Italy, Atmos. Chem. Phys., 14, 9129-9136, doi:10.5194/acp14-9129-2014, 2014b.

Reiss, R., Anderson, E. L., Cross, C. E., Hidy, G., Hoel, D., McClellan, R., and Moolgavkar, S.: Evidence of health impacts of sulfate- and nitrate-containing particles in ambient air, Inhal. Toxicol., 19, 419-449, doi:10.1080/08958370601174941, 2007.

Riffault, V., Zhang, S., Tison, E., and Setyan, A.: Chloride RIE measurements, 14th AMS user meeting, 8 September 2013, available at: http://cires.colorado.edu/jimenez-group/UsrMtgs/ UsersMtg14/AMS_user_meeting_Chl_RIE_riffault.pdf (last access: 10 February 2016), 2013.

Ripoll, A., Minguillón, M. C., Pey, J., Jimenez, J. L., Day, D. A., Sosedova, Y., Canonaco, F., Prévôt, A. S. H., Querol, X., and Alastuey, A.: Long-term real-time chemical characterization of submicron aerosols at Montsec (southern Pyrenees, 1570 m a.s.1.), Atmos. Chem. Phys., 15, 2935-2951, doi:10.5194/acp-15-2935-2015, 2015.

Saarikoski, S., Carbone, S., Decesari, S., Giulianelli, L., Angelini, F., Canagaratna, M., Ng, N. L., Trimborn, A., Facchini, M. C., Fuzzi, S., Hillamo, R., and Worsnop, D.: Chemical characterization of springtime submicrometer aerosol in Po Valley, Italy, Atmos. Chem. Phys., 12, 8401-8421, doi:10.5194/acp-12-84012012, 2012.

Schaap, M., van Loon, M., ten Brink, H. M., Dentener, F. J., and Builtjes, P. J. H.: Secondary inorganic aerosol simulations for Europe with special attention to nitrate, Atmos. Chem. Phys., 4, 857-874, doi:10.5194/acp-4-857-2004, 2004.

Schlesinger, R. B. and Cassee, F.: Atmospheric secondary inorganic particulate matter: the toxicological perspective as a basis for health effects risk assessment, Inhal. Toxicol., 15, 197-235, doi:10.1080/08958370304503, 2003.

Seinfeld, J. H. and Pandis, S. N.: Atmospheric Chemistry and Physics: from Air Pollution to Climate Change, Wiley, New York, USA, 2006.

Sturtz, T. M., Adar, S. D., Gould, T., and Larson, T. V.: Constrained source apportionment of coarse particulate matter and selected trace elements in three cities from the multiethnic study of atherosclerosis, Atmos. Environ., 84, 65-77, doi:10.1016/j.atmosenv.2013.11.031, 2014.

Sun, Y., Wang, Z., Dong, H., Yang, T., Li, J., Pan, X., Chen, P., and Jayne, J. T.: Characterization of summer organic and inorganic aerosols in Beijing, China with an aerosol chemical speciation monitor, Atmos. Environ., 51, 250-259, doi:10.1016/j.atmosenv.2012.01.013, 2012.

Takegawa, N., Miyazaki, Y., Kondo, Y., Komazaki, Y., Miyakawa, T., Jimenez, J. L., Jayne, J. T., Worsnop, D. R., Allan, J. D., and Weber, R. J.: Characterization of an Aerodyne aerosol mass spectrometer (AMS): intercomparison with other aerosol instruments, Aerosol Sci. Technol., 39, 760-770, doi:10.1080/02786820500243404, 2005.
Takegawa, N., Miyakawa, T., Kondo, Y., Jimenez, J. L., Zhang, Q., Worsnop, D. R., and Fukuda, M.: Seasonal and diurnal variations of submicron organic aerosol in Tokyo observed using the Aerodyne aerosol mass spectrometer, J. Geophys. Res.-Atmos., 111, D11206, doi:10.1029/2005JD006515, 2006.

Turpin, B. J. and Lim, H. J.: Species contributions to $\mathrm{PM}_{2.5}$ mass concentrations: revisiting common assumptions for estimating organic mass, Aerosol Sci. Technol., 35, 602-610, doi:10.1080/02786820152051454, 2001.

Turpin, B. J., Saxena, P., and Andrews, E.: Measuring and simulating particulate organics in the atmosphere: problems and prospects, Atmos. Environ., 34, 2983-3013, 2000.

Ulbrich, I. M., Canagaratna, M. R., Zhang, Q., Worsnop, D. R., and Jimenez, J. L.: Interpretation of organic components from Positive Matrix Factorization of aerosol mass spectrometric data, Atmos. Chem. Phys., 9, 2891-2918, doi:10.5194/acp-9-2891-2009, 2009.

Ulbrich, I. M., Lechner, M., and Jimenez, J. L.: AMS Spectral Database, available at: http://cires.colorado.edu/jimenez-group/ AMSsd/, last access: 7 October 2015.

van Donkelaar, A., Martin, R. V., Brauer, M., Kahn, R., Levy, R., Verduzco, C., and Villeneuve, P. J.: Global estimates of ambient fine particulate matter concentrations from satellite-based aerosol optical depth: development and application, Environ. Health Persp., 118, 847-855, doi:10.1289/ehp.0901623, 2010.

Volkamer, R., Jimenez, J. L., San Martini, F., Dzepina, K., Zhang, Q., Salcedo, D., Molina, L. T., Worsnop, D. R., and Molina, M. J.: Secondary organic aerosol formation from anthropogenic air pollution: rapid and higher than expected, Geophys. Res. Lett., 33, L17811, doi:10.1029/2006GL026899, 2006.

Watson, J. G., Chow, J. C., Chen, L.-W. A., and Frank, N. H.: Methods to assess carbonaceous aerosol sampling artifacts for IMPROVE and other long-term networks, J. Air Waste Manage. Assoc., 59, 898-911, doi:10.3155/1047-3289.59.8.898, 2009.

Weimer, S., Drewnick, F., Hogrefe, O., Schwab, J. J., Rhoads, K., Orsini, D., Canagaratna, M., Worsnop, D. R., and Demerjian, K. L.: Size-selective nonrefractory ambient aerosol measurements during the particulate matter technology assessment and characterization study - New York 2004 winter intensive in New York City, J. Geophys. Res., 111, D18305, doi:10.1029/2006JD007215, 2006.

WHO: WHO Air quality guidelines for particulate matter, ozone, nitrogen dioxide and sulfur dioxide: global update 2005: summary of risk assessment, available at: http://apps.who.int/iris/ handle/10665/69477 (last access: 10 October 2014), 2006.

WHO: Review of evidence on health aspects of air pollution_REVIHAAP Project, Technical Report, available at: http://www.euro.who.int/_data/assets/pdf_file/0004/193108/ REVIHAAP-Final-technical-report-final-version.pdf (last access: 15 April 2015), 2013.

Wiedensohler, A., Birmili, W., Nowak, A., Sonntag, A., Weinhold, K., Merkel, M., Wehner, B., Tuch, T., Pfeifer, S., Fiebig, M., Fjäraa, A. M., Asmi, E., Sellegri, K., Depuy, R., Venzac, H., Villani, P., Laj, P., Aalto, P., Ogren, J. A., Swietlicki, E., Williams, P., Roldin, P., Quincey, P., Hüglin, C., Fierz-Schmidhauser, R., Gysel, M., Weingartner, E., Riccobono, F., Santos, S., Grüning, C., Faloon, K., Beddows, D., Harrison, R., Monahan, C., Jennings, S. G., O’Dowd, C. D., Marinoni, A., Horn, H.-G., Keck, L., Jiang, J., Scheckman, J., McMurry, P. H., Deng, Z., Zhao, C. 
S., Moerman, M., Henzing, B., de Leeuw, G., Löschau, G., and Bastian, S.: Mobility particle size spectrometers: harmonization of technical standards and data structure to facilitate high quality long-term observations of atmospheric particle number size distributions, Atmos. Meas. Tech., 5, 657-685, doi:10.5194/amt5-657-2012, 2012.

WMO, Zhu, T., Melamed, M., Parrish, D., Gauss, M., Gallardo Klenner, L., Lawrence, M., Konare, A., and Liousse, C.: WMO/IGAC impacts of megacities on air pollution and climate, available at: http://library.wmo.int/pmb_ged/gaw_205.pdf (last access: 29 July 2015), 2012.

Young, D. E., Allan, J. D., Williams, P. I., Green, D. C., Harrison, R. M., Yin, J., Flynn, M. J., Gallagher, M. W., and Coe, H.: Investigating a two-component model of solid fuel organic aerosol in London: processes, PM1 contributions, and seasonality, Atmos. Chem. Phys., 15, 2429-2443, doi:10.5194/acp-152429-2015, 2015.

Zhang, Q.: Time- and size-resolved chemical composition of submicron particles in Pittsburgh: implications for aerosol sources and processes, J. Geophys. Res., 110, D07S09, doi:10.1029/2004JD004649, 2005.
Zhang, Q., Jimenez, J. L., Canagaratna, M. R., Allan, J. D., Coe, H., Ulbrich, I., Alfarra, M. R., Takami, A., Middlebrook, A. M., Sun, Y. L., Dzepina, K., Dunlea, E., Docherty, K., DeCarlo, P. F., Salcedo, D., Onasch, T., Jayne, J. T., Miyoshi, T., Shimono, A., Hatakeyama, S., Takegawa, N., Kondo, Y., Schneider, J., Drewnick, F., Borrmann, S., Weimer, S., Demerjian, K., Williams, P., Bower, K., Bahreini, R., Cottrell, L., Griffin, R. J., Rautiainen, J., Sun, J. Y., Zhang, Y. M., and Worsnop, D. R.: Ubiquity and dominance of oxygenated species in organic aerosols in anthropogenically-influenced Northern Hemisphere midlatitudes, Geophys. Res. Lett., 34, L13801, doi:10.1029/2007GL029979, 2007.

Zhang, Q., Jimenez, J. L., Canagaratna, M. R., Ulbrich, I. M., Ng, N. L., Worsnop, D. R., and Sun, Y.: Understanding atmospheric organic aerosols via factor analysis of aerosol mass spectrometry: a review, Anal. Bioanal. Chem., 401, 3045-3067, doi:10.1007/s00216-011-5355-y, 2011. 